\title{
Flexibility of a Metal-Organic Framework Enhances Gas Separation and Enables Quantum Sieving
}

\author{
Omid T. Qazvini, ${ }^{\text {, }} \underset{ }{ }$ Victoria-Jayne Scott, ${ }^{\ddagger}$ Linda Bondorf, ${ }^{€}$ Maxime Ducamp, ${ }^{\ddagger}$ Michael Hirscher, ${ }^{€}$ \\ François-Xavier Coudert, ${ }^{f}$ and Shane G. Telfer*¥ \\ ¥ MacDiarmid Institute for Advanced Materials and Nanotechnology, School of Fundamental Sciences, \\ Massey University, Palmerston North 4410, New Zealand. \\ ${ }^{E}$ Department of Chemical Engineering and Analytical Science, The University of Manchester, Oxford Road, \\ Manchester M13 9PL, UK. \\ ${ }^{€}$ Max Planck Institute for Intelligent Systems, Heisenbergstraße 3, 70569 Stuttgart, Germany. \\ ${ }^{\mathrm{f}}$ Chimie ParisTech, PSL Research University, CNRS, Institut de Recherche de Chimie Paris, 75005 Paris, \\ France.
}

\section{Contents}

1. Synthesis ........................................................................................... 2

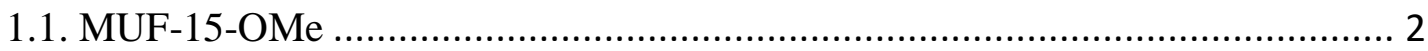

1.2. MUF-15-OMe doped with isophthalic acid.......... Error! Bookmark not defined.

2. Single-crystal and powder X-ray diffraction ............................................. 2

3. Thermogravimetric analysis .............................................................. 7

4. Structure, physical properties and pore shape …........................................ 8

5. Gas adsorption measurements ....................................................... 8

6. Calculation of BET surface areas........................................................... 11

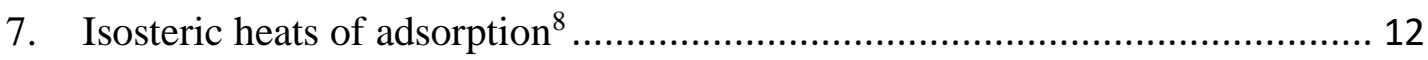

8. Breakthrough separation experiments and simulations ................................ 14

8.1. Single gas breakthrough experiments ..................................................... 14

8.2. Mixed gas breakthrough experiments..................................................... 15

8.3. Simulations of breakthrough curves ...................................................... 15

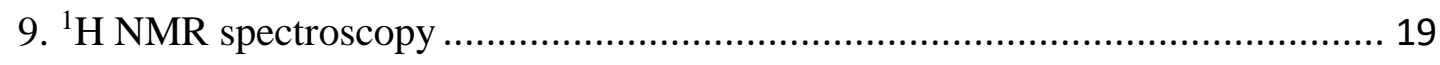

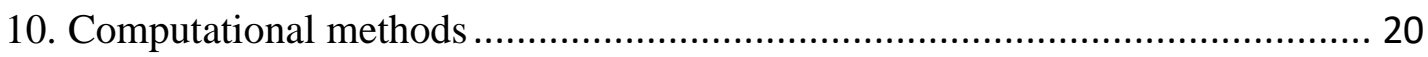

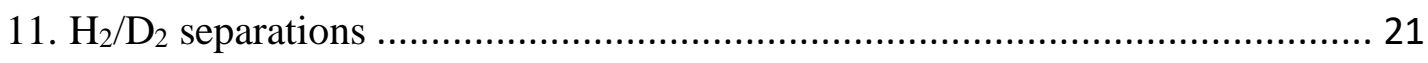

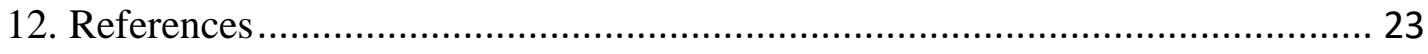




\section{Synthesis}

All starting reactants and solvents were obtained from commercial sources and used without further purification.

\subsection{MUF-15-OMe}

Method for SCXRD crystals: A mixture of $\mathrm{Co}(\mathrm{OAc})_{2} \cdot 4 \mathrm{H}_{2} \mathrm{O}(0.125 \mathrm{~g}, 0.5 \mathrm{mmol})$, 5-methoxyisophthalic acid (0.171 g, $0.875 \mathrm{mmol}), \mathrm{MeOH}(3.5 \mathrm{~mL}), \mathrm{EtOH}(3.5 \mathrm{~mL})$ and $\mathrm{H}_{2} \mathrm{O}(0.5 \mathrm{~mL})$ was sonicated for $20 \mathrm{~min}$ and sealed in a $25 \mathrm{ml}$ Teflonlined autoclave and heated to $120{ }^{\circ} \mathrm{C}$ for 48 hours. After cooling to the room temperature, the resulting purple crystals were washed with methanol several times.

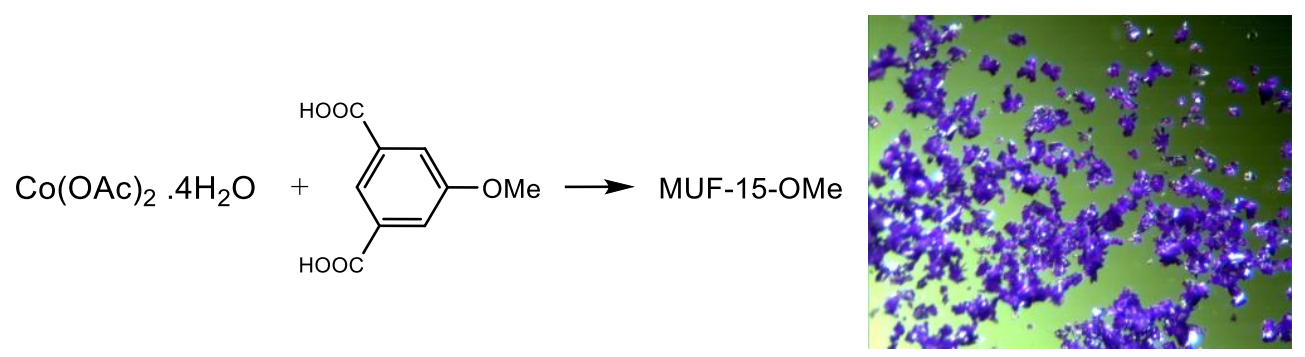

Figure S1. Synthetic route to MUF-15-OMe with an optical micrograph of the product.

\section{Single-crystal and powder $\mathrm{X}$-ray diffraction}

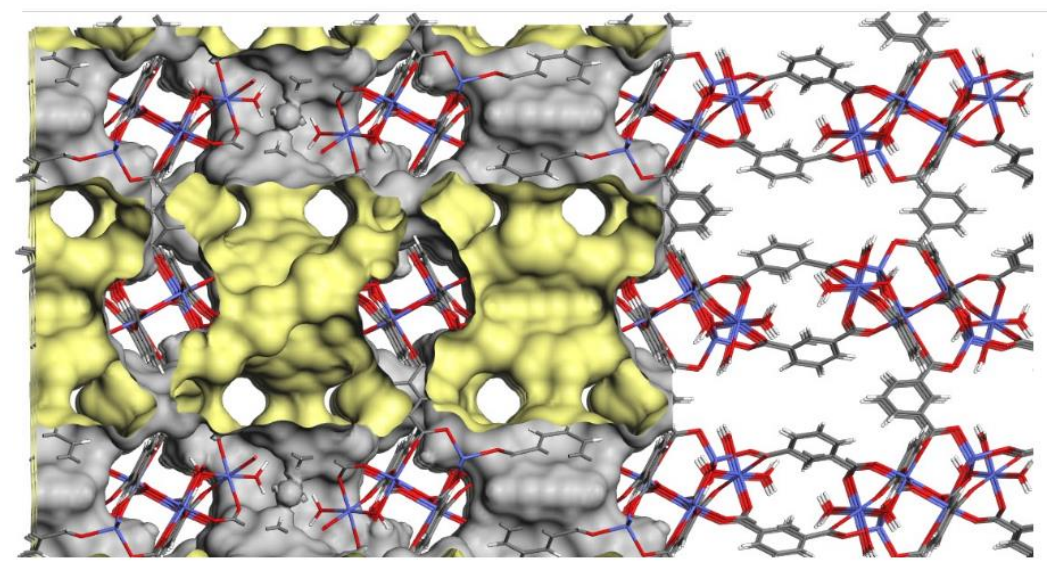

Figure S2. Internal structure of the network of pores in MUF-15 illustrated by the Connolly surface in yellow (probe of diameter $1.0 \AA$ ). 
Table S1. Crystal data and refinement details for MUF-15-OMe.

\begin{tabular}{|c|c|}
\hline CCDC number & 2055679 \\
\hline Formula & {$\left[\mathrm{Co}_{6}\left(\mu_{3}-\mathrm{OH}\right)_{2}(\mathrm{ip}-\mathrm{OMe})_{5}\left(\mathrm{H}_{2} \mathrm{O}\right)_{4}\right] \cdot\left(\mathrm{H}_{2} \mathrm{O}\right)_{3}$} \\
\hline Empirical formula & $\mathrm{C}_{45} \mathrm{H}_{46} \mathrm{Co}_{6} \mathrm{O}_{34}$ \\
\hline Formula weight & 1484.40 \\
\hline Temperature/K & 293 \\
\hline Crystal system & orthorhombic \\
\hline Space group & $P 2{ }_{1} 2{ }_{1}$ \\
\hline $\mathrm{a} / \AA$ & $22.57(5)$ \\
\hline $\mathrm{b} / \AA$ & $28.68(6)$ \\
\hline $\mathrm{c} / \AA$ & $10.94(3)$ \\
\hline$\alpha /^{\circ}$ & 90 \\
\hline$\beta /{ }^{\circ}$ & 90 \\
\hline$\gamma /{ }^{\circ}$ & 90 \\
\hline Volume $/ \AA^{3}$ & $7082(29)$ \\
\hline $\mathrm{Z}$ & 4 \\
\hline$\rho_{\text {calc }} / \mathrm{g} \mathrm{cm}^{-3}$ & 1.392 \\
\hline$\mu / \mathrm{mm}^{-1}$ & 11.456 \\
\hline $\mathrm{F}(000)$ & 3000.0 \\
\hline Radiation & $\lambda=1.54178$ \\
\hline $2 \Theta$ range for data collection ${ }^{\circ}$ & 4.982 to 117.024 \\
\hline Index ranges & $-24 \leq \mathrm{h} \leq 24,-31 \leq \mathrm{k} \leq 30,-11 \leq 1 \leq 12$ \\
\hline Reflections collected & 158767 \\
\hline Independent reflections & $\begin{array}{c}9939\left[R_{\text {int }}=0.1463,\right. \\
\left.R_{\text {sigma }}=0.0754\right]\end{array}$ \\
\hline Data/restraints/parameters & $9939 / 32 / 746$ \\
\hline Goodness-of-fit on $\mathrm{F}^{2}$ & 1.099 \\
\hline Final $R$ indexes $[\mathrm{I}>=2 \sigma(\mathrm{I})]$ & $\mathrm{R}_{1}=0.1107, \mathrm{wR}_{2}=0.2641$ \\
\hline Final $\mathrm{R}$ indexes [all data] & $\mathrm{R}_{1}=0.1463, \mathrm{wR}_{2}=0.2985$ \\
\hline Largest diff. peak/hole / e $\AA^{-3}$ & $1.71 /-0.80$ \\
\hline Flack parameter & $0.425(13)$ \\
\hline
\end{tabular}

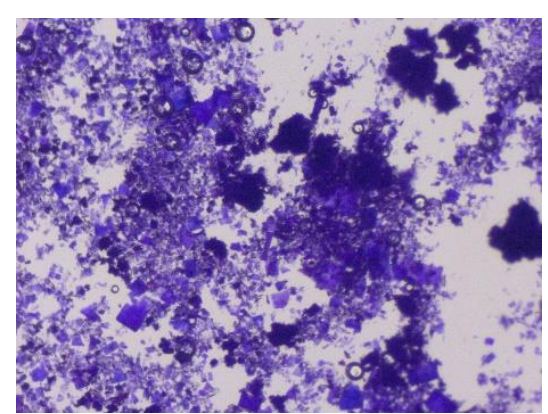

Figure S3. Optical micrograph of $\left[\mathrm{Co}_{6}\left(\mu_{3}-\mathrm{OH}\right)_{2}(\mathrm{ipa})_{0.59}(\mathrm{ipa}-\mathrm{OMe})_{4.42}\left(\mathrm{H}_{2} \mathrm{O}\right)_{4}\right]$

Table S2. Unit cell details for MUF-15-OMe doped with isophthalic acid (88.3\% ipa-OMe).

\begin{tabular}{|l|c|}
\hline Formula & {$\left[\mathrm{Co}_{6}\left(\mu_{3}-\mathrm{OH}\right)_{2}(\mathrm{ipa})_{0.59}(\mathrm{ipa}-\mathrm{OMe})_{4.42}\left(\mathrm{H}_{2} \mathrm{O}\right)_{4}\right]$} \\
\hline Temperature/K & 293 \\
\hline Crystal system & orthorhombic \\
\hline a/ $\AA$ & 22.39 \\
\hline b/ $\AA$ & 28.54 \\
\hline
\end{tabular}




\begin{tabular}{|l|c|}
\hline$c / \AA$ & 10.89 \\
\hline$\alpha /^{\circ}$ & 90 \\
\hline$\beta /{ }^{\circ}$ & 90 \\
\hline$\gamma /{ }^{\circ}$ & 90 \\
\hline Volume $/ \AA^{3}$ & 6959 \\
\hline
\end{tabular}

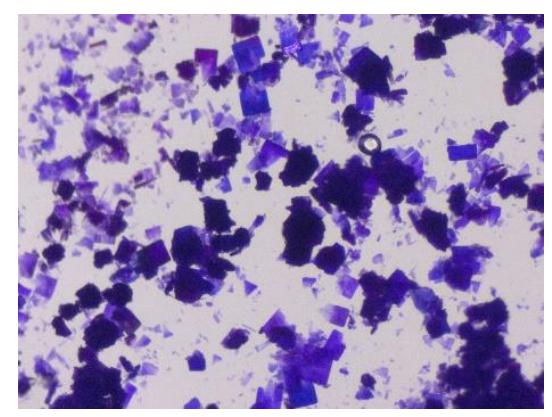

Figure S4. Optical micrograph of $\left[\mathrm{Co}_{6}\left(\mu_{3}-\mathrm{OH}\right)_{2}(\mathrm{ipa})_{0.33}(\mathrm{ipa}-\mathrm{OMe})_{4.68}\left(\mathrm{H}_{2} \mathrm{O}\right)_{4}\right]$.

Table S3. Unit cell details for MUF-15-OMe doped with isophthalic acid (93.5\% ipa-OMe).

\begin{tabular}{|l|c|}
\hline Formula & {$\left[\mathrm{Co}_{6}\left(\mu_{3}-\mathrm{OH}\right)_{2}(\mathrm{ipa})_{0.33}(\mathrm{ipa}-\mathrm{OMe})_{4.68}\left(\mathrm{H}_{2} \mathrm{O}\right)_{4}\right]$} \\
\hline Temperature $/ \mathrm{K}$ & 293 \\
\hline Crystal system & orthorhombic \\
\hline $\mathrm{a} / \AA$ & 22.65 \\
\hline $\mathrm{b} / \AA$ & 28.61 \\
\hline $\mathrm{c} / \AA$ & 10.92 \\
\hline$\alpha /^{\circ}$ & 90 \\
\hline$\beta /{ }^{\circ}$ & 90 \\
\hline$\gamma /{ }^{\circ}$ & 90 \\
\hline Volume $/ \AA^{3}$ & 7073 \\
\hline
\end{tabular}



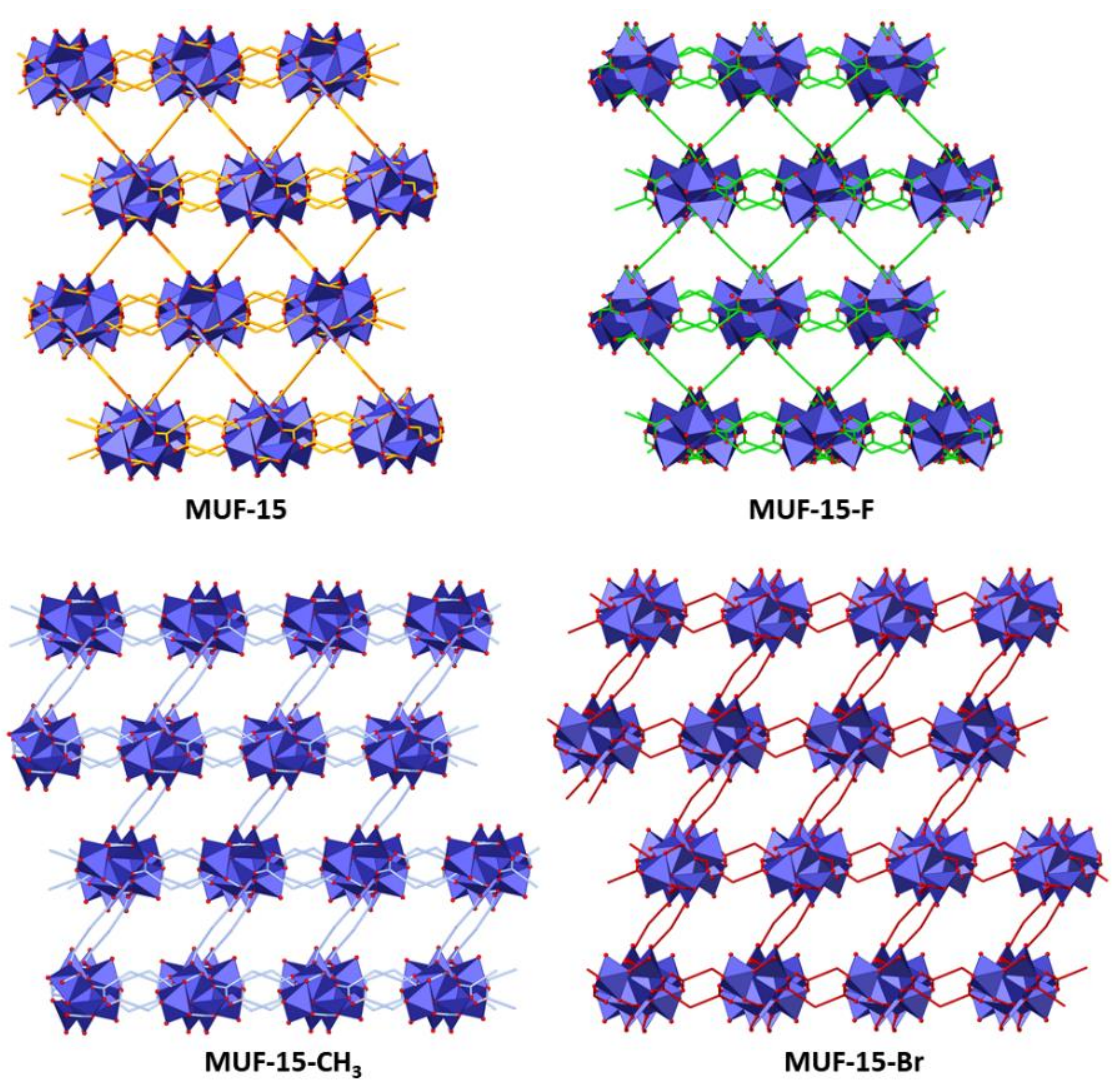

Figure S5. Network structures of MUF-15 derivatives highlighting the different orientations of the axial liagnds: zig-zag for MUF-15 (space group Pnna) and MUF-15-F (space group Pna $2_{1}$ ), and mutually tilted for MUF-15- $\mathrm{CH}_{3}$ and MUF$15-\mathrm{Br}$ (both space group $P 2_{1} / \mathrm{n}$ ). Cobalt ions are shown as blue polyhedra, ithe isophthalate ligands shown as coloured rods, and the $\mathrm{O}$ atoms as red spheres. The related view of MUF-15-OMe is shown in the main manuscript.

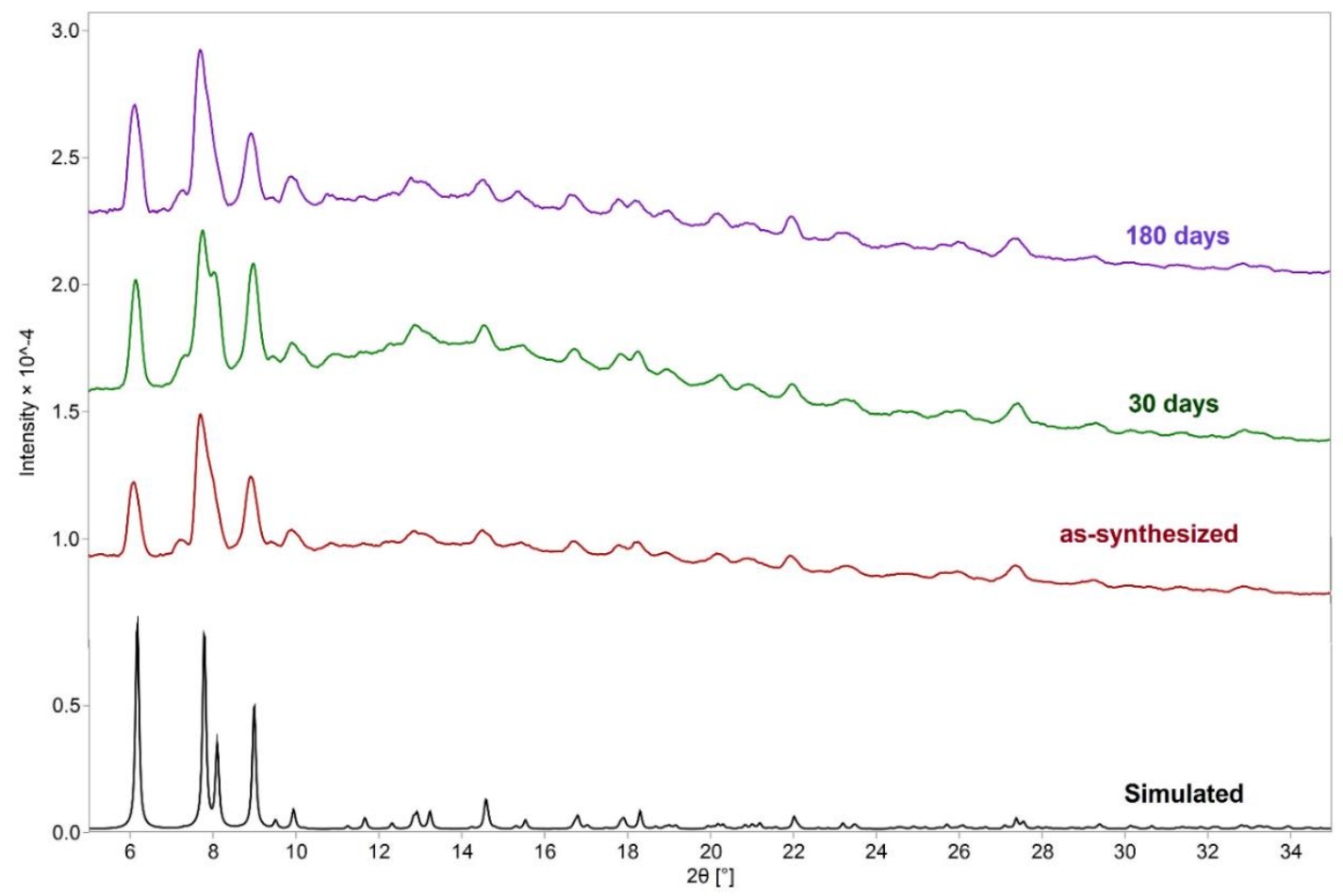

Figure S6. PXRD diffraction patterns of MUF-15-OMe; simulated, as-synthesized and aged samples exposed to 70-80\% relative humidity at $20^{\circ} \mathrm{C}$ for the stated period. 


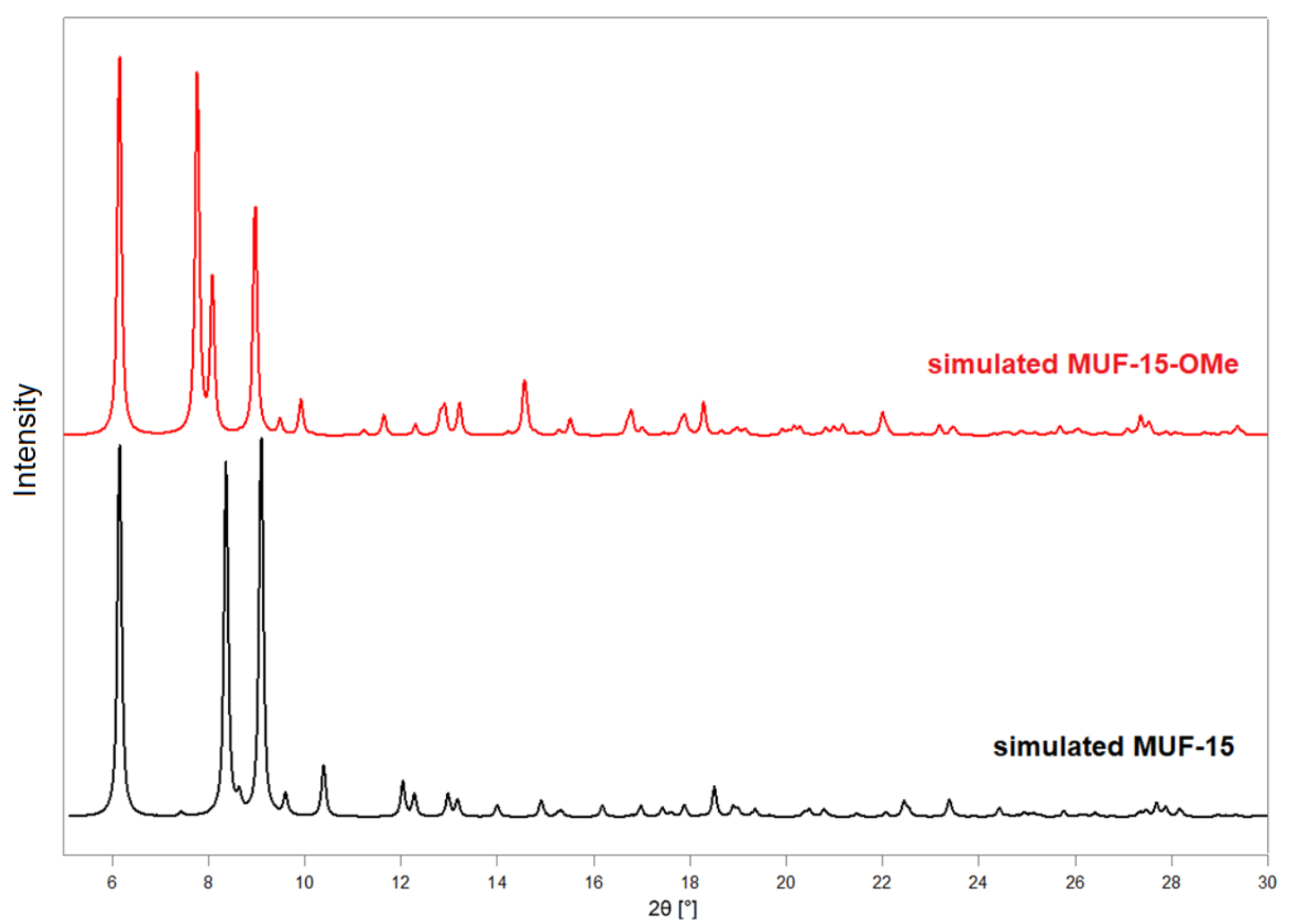

Figure S7. Simulated PXRD diffraction pattern of MUF-15-OMe in comparison to that of MUF-15.

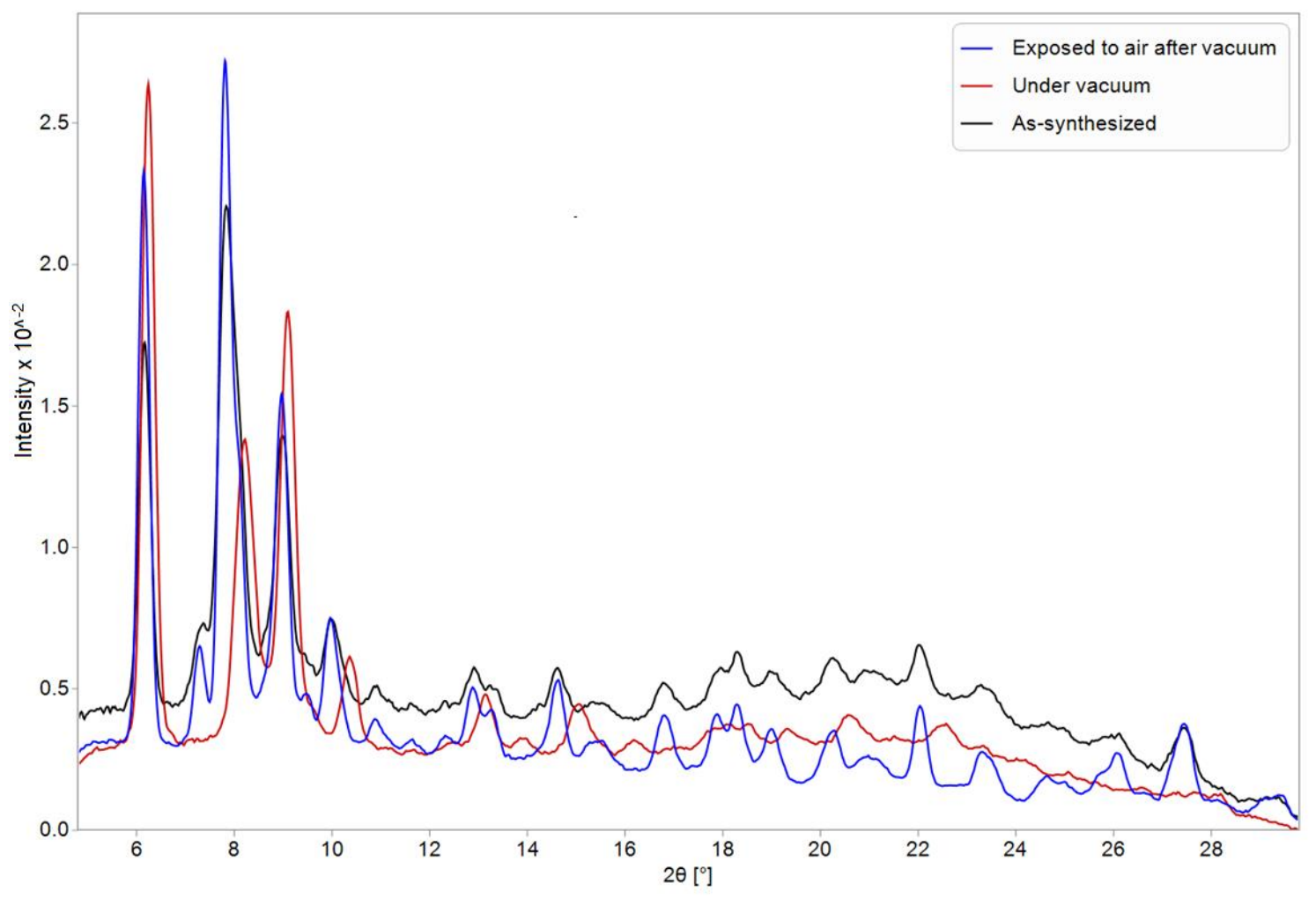

Figure S8. PXRD pattern of MUF-15-OMe under vacuum in comparison to its as-synthesized state and after removing it from the vacuum and exposing it to the atmosphere. 


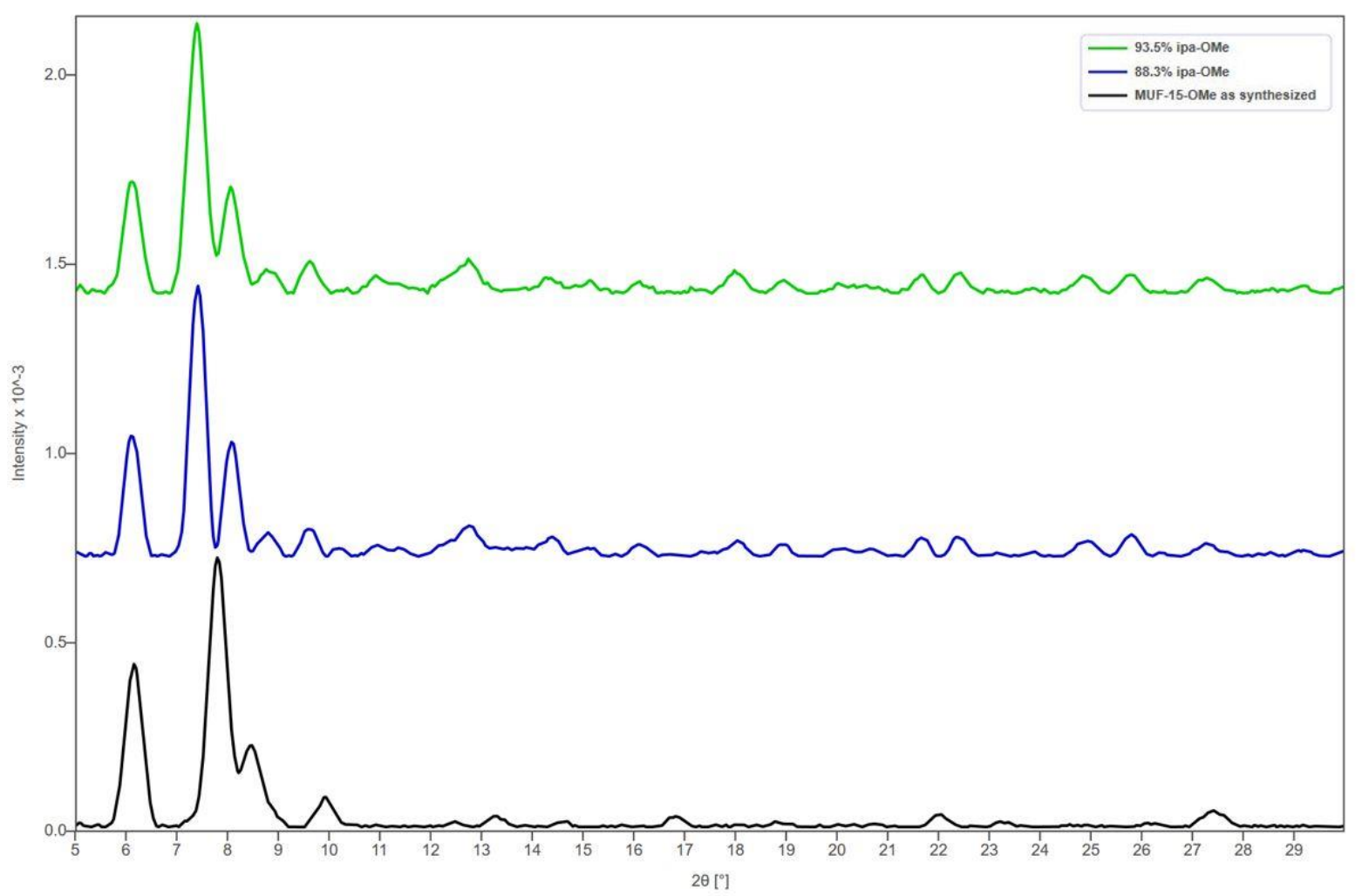

Figure S9. PXRD patterns of pure MUF-15-OMe (as synthesized, black), and doped with ipa; $\left[\mathrm{Co}_{6}\left(\mu_{3}-\mathrm{OH}\right)_{2}(\mathrm{ipa})_{0.59}(\mathrm{ipa}-\right.$ $\left.\mathrm{OMe})_{4.42}\left(\mathrm{H}_{2} \mathrm{O}\right)_{4}\right]$ is blue and $\left[\mathrm{Co}_{6}\left(\mu_{3}-\mathrm{OH}\right)_{2}(\mathrm{ipa})_{0.33}(\mathrm{ipa}-\mathrm{OMe})_{4.68}\left(\mathrm{H}_{2} \mathrm{O}\right)_{4}\right]$ is green.

\section{Thermogravimetric analysis}

Thermogravimetric analysis was performed using a TA Instruments Q50 instrument with approximately 5 mg of activated sample under a $\mathrm{N}_{2}$ flow with a heating rate of $5{ }^{\circ} \mathrm{C} / \mathrm{min}$. Weight loss at low temperatures is attributed to the removal of water vapor trapped in the framework pores.

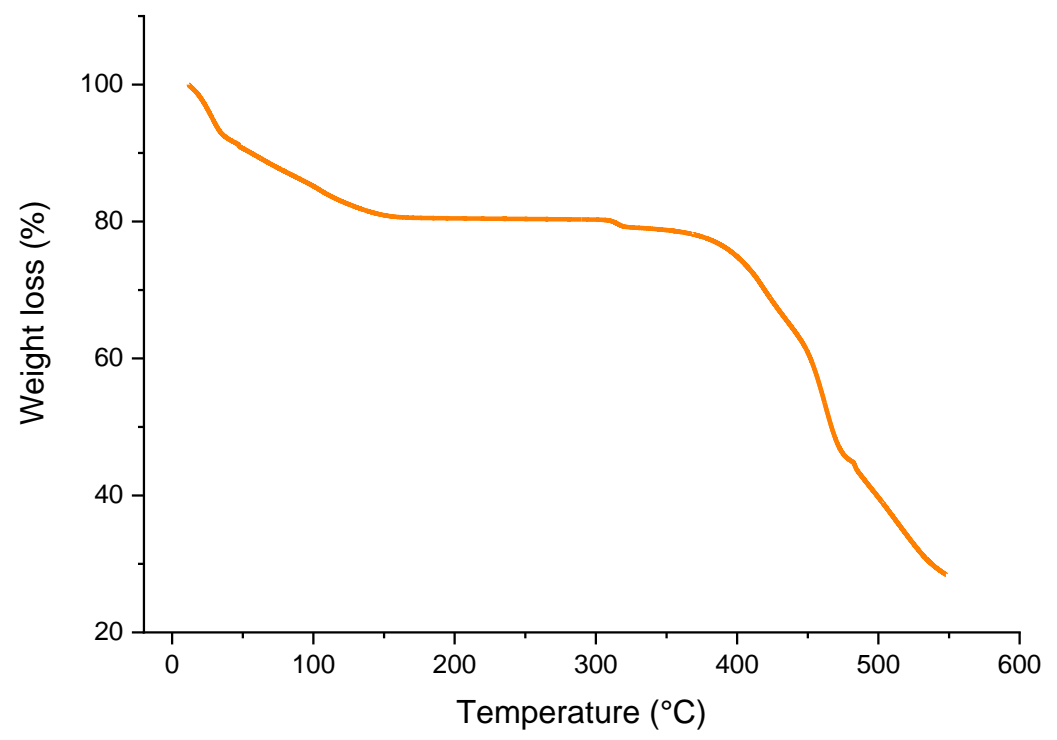

Figure S10. TGA curve of MUF-15-OMe. 

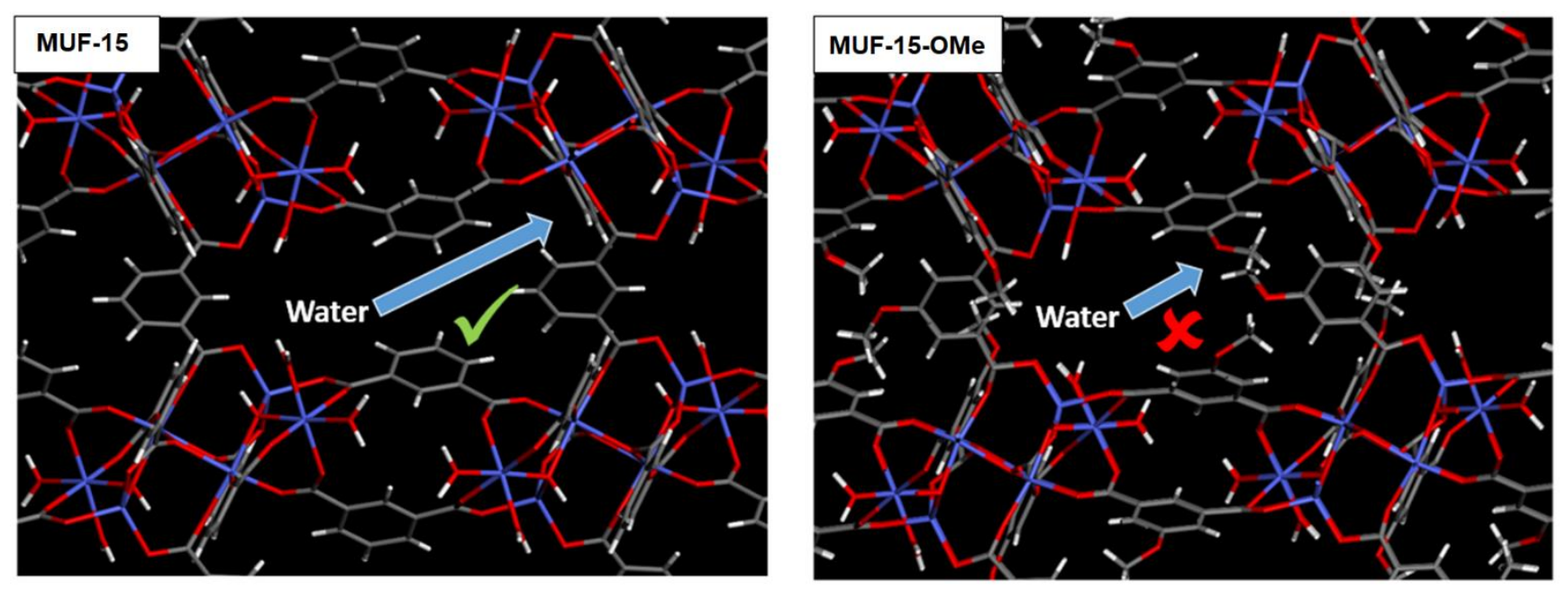

Figure S11. Left: Water molecules may access the cobalt clusters in MUF-15. Right: Access of water molecules to the cobalt clusters in MUF-15-OMe, may be blocked by the methoxy groups.

\section{Structure, physical properties and pore shape}

The Zeo $++{ }^{1}$ code and RASPA $2^{2}$ were used to characterize the geometric features of the framework by calculating the pore volume (with the use of a helium probe) and surface area (with the use of a $\mathrm{H}_{2}$ probe). Accelrys Materials Studio 7.0 software package was performed to visualize the MOF structure and pore topology.

\section{Gas adsorption measurements}

The adsorption isotherms were measured with a volumetric adsorption apparatus (Quantachrome-Autosorb-iQ2). Ultrahigh purity gases were used as received from BOC Gases. The as-synthesized samples were washed with dry methanol several times and 50-100 mg was transferred into a pre-dried and weighed sample tube and heated at rate of $10^{\circ} \mathrm{C} / \mathrm{min}$ to a temperature of $120{ }^{\circ} \mathrm{C}$ under a dynamic vacuum at $10^{-6}$ torr then held for $20 \mathrm{~h}$. Accurate sample masses were calculated using degassed samples afterwards the sample tube was backfilled with nitrogen. The temperature at $77 \mathrm{~K}$ was controlled by a Dewar filled with liquid $\mathrm{N}_{2}$. Around room temperatures, the bath temperature was precisely controlled with a recirculating thermostatted bath containing a mixture of ethylene glycol and water.

Table S4. Physicochemical characteristics of different gasses relevant to their separation. ${ }^{3-6}$

\begin{tabular}{cccccc}
\hline & $\begin{array}{c}\text { Boiling } \\
\text { point }(\mathrm{K})\end{array}$ & $\begin{array}{c}\text { Molecular } \\
\text { dimensions }(\AA)\end{array}$ & $\begin{array}{c}\text { Polarizability } \\
\left(\AA^{3}\right)\end{array}$ & $\begin{array}{c}\text { Dipole moment } \\
\times 10^{18} / \mathrm{esu} \mathrm{cm}^{2}\end{array}$ & $\begin{array}{c}\text { Quadrupole moment } \\
\times 10^{26} / \mathrm{esu} \mathrm{cm}^{2}\end{array}$ \\
\hline $\mathrm{C}_{2} \mathrm{H}_{2}$ & 188.4 & $3.32 \times 3.34 \times 5.7$ & $3.33-3.93$ & 0 & +7.5 \\
$\mathrm{CO}_{2}$ & 216.5 & $3.18 \times 3.33 \times 5.36$ & 2.91 & 0 & -4.3 \\
$\mathrm{C}_{2} \mathrm{H}_{4}$ & 169.4 & $3.28 \times 4.18 \times 4.84$ & 4.25 & 0 & +1.5 \\
$\mathrm{C}_{2} \mathrm{H}_{6}$ & 184.5 & $3.81 \times 4.82 \times 4.08$ & $4.43-4.47$ & 0 & +0.65 \\
$\mathrm{C}_{3} \mathrm{H}_{8}$ & 231.0 & $6.80 \times 4.20 \times 3.80$ & $6.29-6.37$ & 0.084 & - \\
$\mathrm{C}_{3} \mathrm{H}_{6}$ & 225.4 & - & 6.26 & 0.366 & - \\
\hline
\end{tabular}




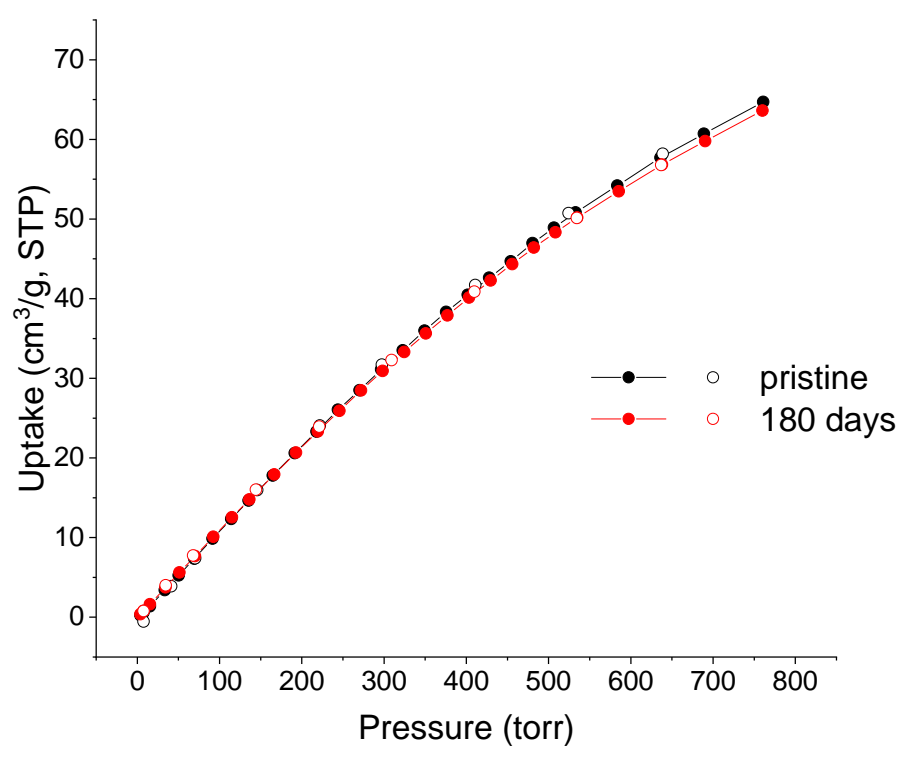

Figure S12. $\mathrm{CO}_{2}$ adsorption (filled circles) and desorption (open circles) isotherms measured at $293 \mathrm{~K}$ for pristine and aged MUF-15-OMe under 70-80\% relative humidity.

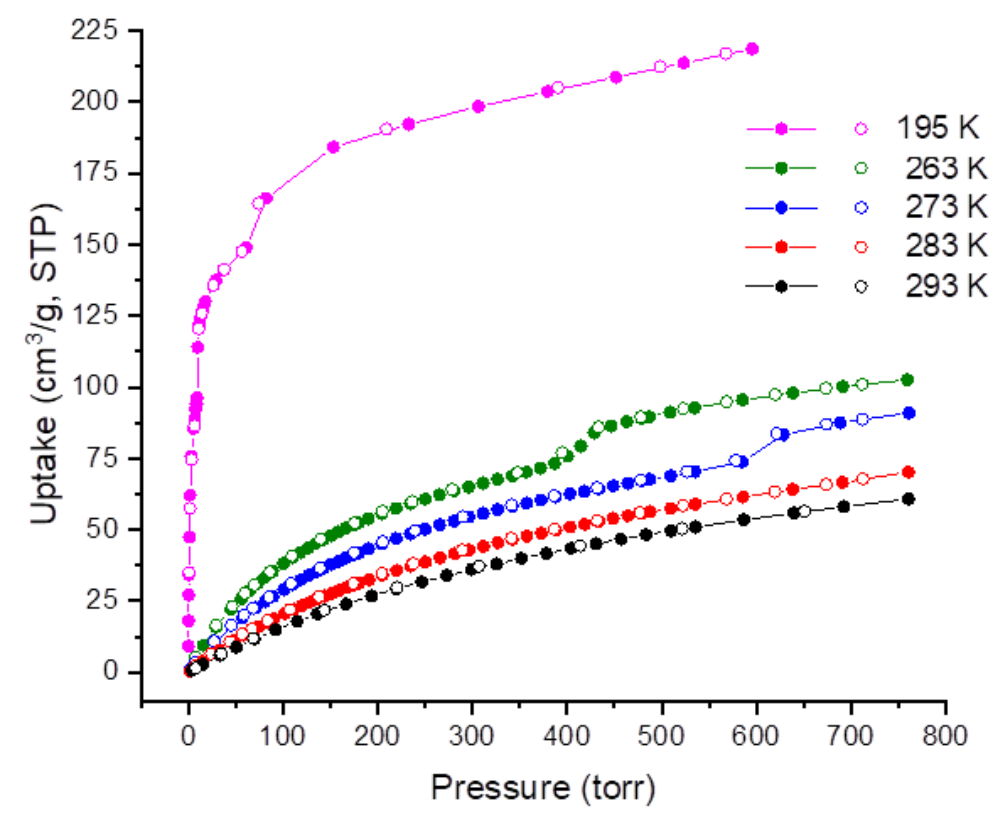

Figure S13. Volumetric adsorption (filled circles) and desorption (open circles) isotherms of $\mathrm{CO}_{2}$ on $\mathrm{MUF}-15-\mathrm{OMe}$. A comparison of the isotherms at different temperatures suggests that the gate opening pressure might moves above 1 bar at temperatures greater than $283 \mathrm{~K}$. 


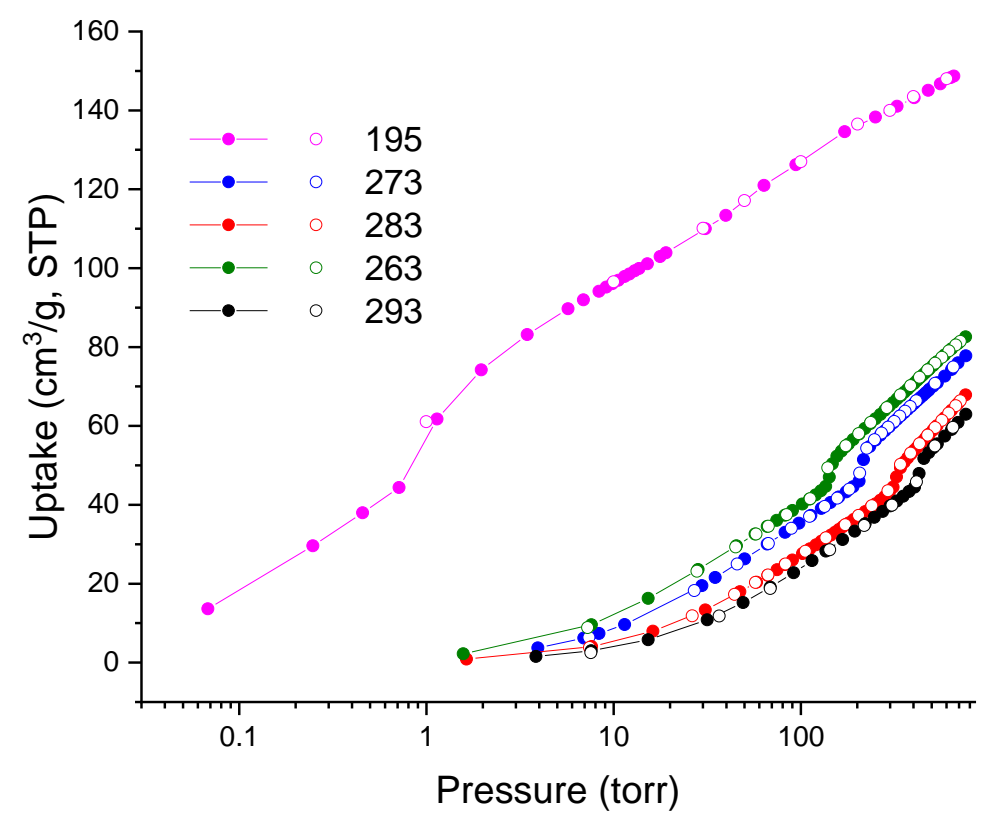

Figure S14. Volumetric adsorption (filled circles) and desorption (open circles) isotherms of $\mathrm{C}_{2} \mathrm{H}_{4}$ by MUF-15-OMe at $195 \mathrm{~K}$ in comparison to higher temperatures, showing the movement of the gate opening step to higher pressure (log scale).

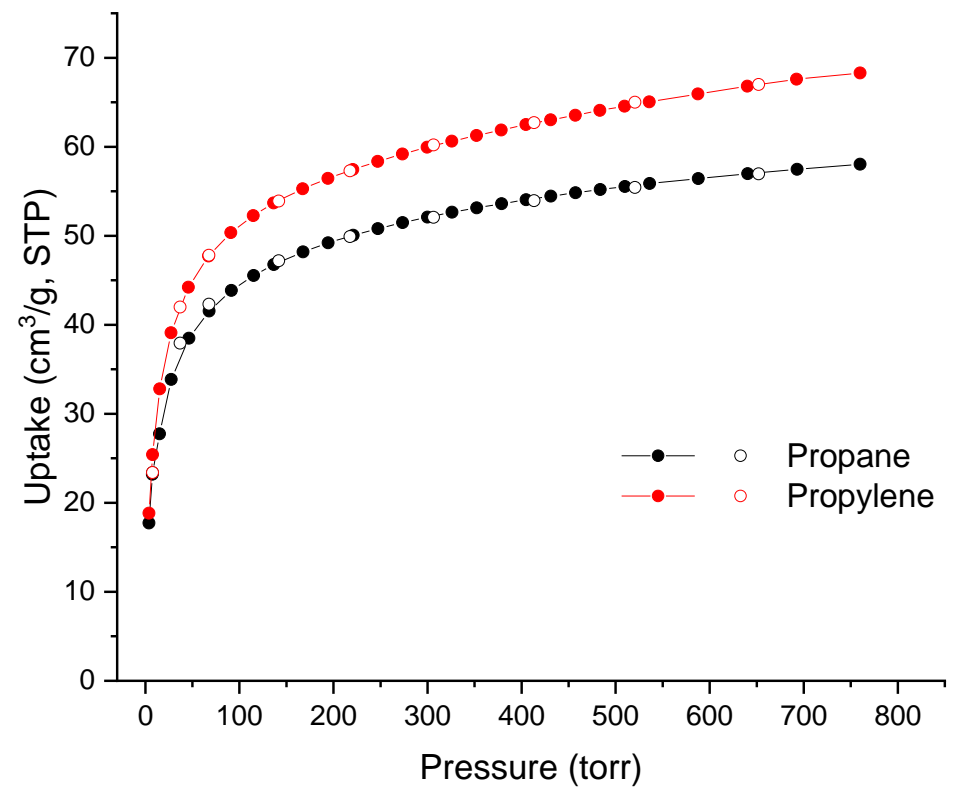

Figure S15. Volumetric adsorption (filled circles) and desorption (open circles) isotherms of $\mathrm{C}_{3} \mathrm{H}_{8}$ and $\mathrm{C}_{3} \mathrm{H}_{6}$ by MUF$15-\mathrm{OMe}$ at $293 \mathrm{~K}$. 


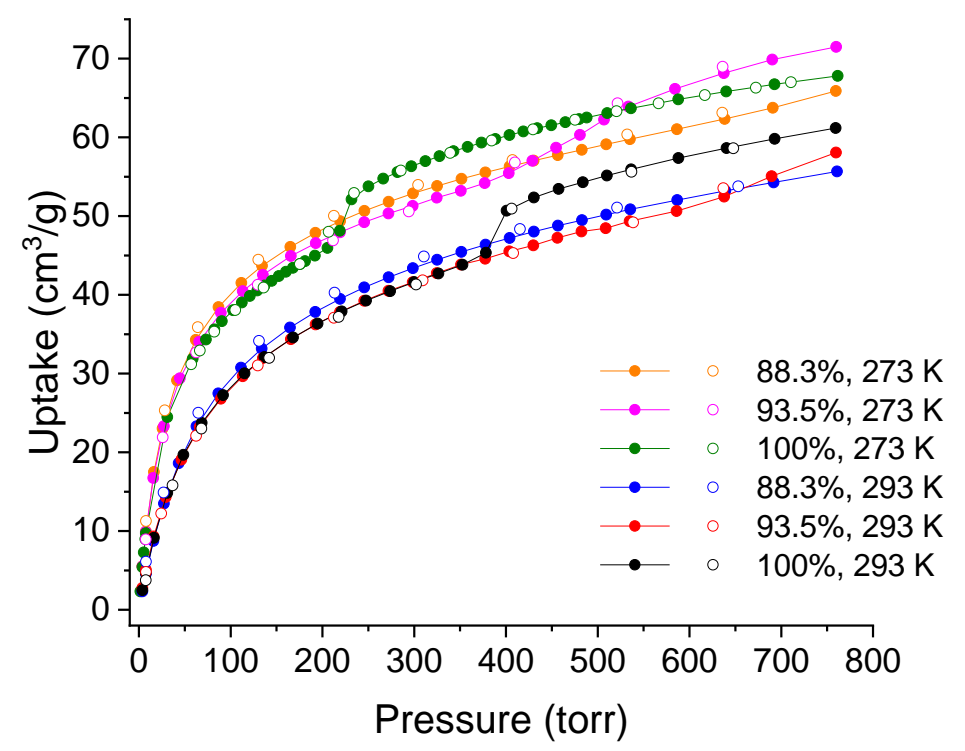

Figure S16. Volumetric adsorption (filled circles) and desorption (open circles) isotherms of $\mathrm{C}_{2} \mathrm{H}_{6}$ measured at $273 \mathrm{~K}$ and $293 \mathrm{~K}$ for MUF-15-OMe doped with small quantities of isophthalic acid. The percentages represent how much ipaOMe is present in the framework (the balance being ipa). The overall formula is $\left[\mathrm{Co}_{6}\left(\mu_{3}-\mathrm{OH}\right)_{2}(\mathrm{ipa}-\mathrm{OMe})_{\mathrm{x}}(\mathrm{ipa})_{\mathrm{y}}\left(\mathrm{H}_{2} \mathrm{O}\right)_{4}\right]_{\text {. }}$

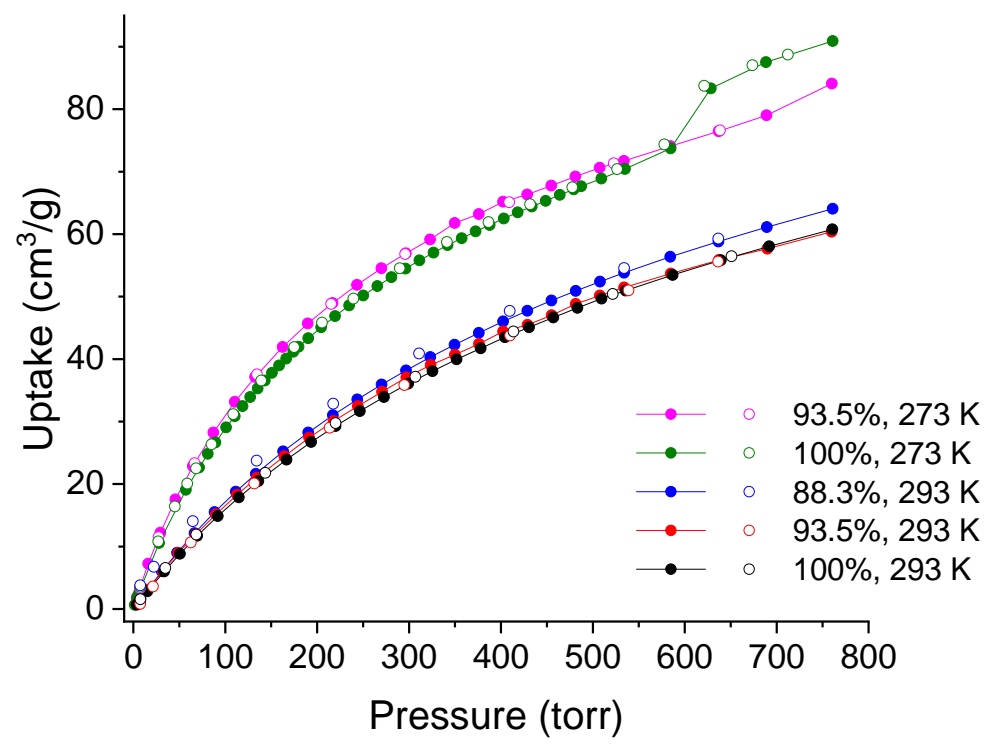

Figure S17. Volumetric adsorption (filled circles) and desorption (open circles) isotherms of $\mathrm{CO}_{2}$ measured at $273 \mathrm{~K}$ and $293 \mathrm{~K}$ for MUF-15-OMe doped with small quantities of isophthalic acid. The percentage shown represents how much ipa-OMe is present in the framework (the balance being ipa). The overall formula is $\left[\mathrm{Co}_{6}\left(\mu_{3}-\mathrm{OH}\right)_{2}(\mathrm{ipa}-\right.$

$\left.\mathrm{OMe})_{\mathrm{x}}(\mathrm{ipa})_{\mathrm{y}}\left(\mathrm{H}_{2} \mathrm{O}\right)_{4}\right]$.

\section{Calculation of BET surface areas}

The BET surface area was calculated from the $\mathrm{N}_{2}$ adsorption isotherm at $77 \mathrm{~K}$ according to the following procedures ${ }^{7}$ : 
1) The isotherm region where $v\left(1-P / P_{0}\right)$ increases versus $P / P_{0}$, where $v$ is the amount of $\mathrm{N}_{2}$ adsorbed, was identified.

2) Within this isotherm region, sequential data points that led to a positive intercept in the plot of $\frac{P / P_{0}}{v\left(1-P / P_{0}\right)}$ against $P / P_{0}$, were found. This plot yields a slope $a$, and a positive intercept $b$. The amount of gas molecules adsorbed in the initial monolayer is $v_{m}=\frac{1}{a+b}$.

3) The BET surface area was calculated according to the following equation:

$$
A_{B E T}=v_{m}\left(\mathrm{~cm}^{3} \mathrm{~g}^{-1}\right) * \frac{1(\mathrm{~mol})}{22400\left(\mathrm{~cm}^{3}\right)} * \sigma_{0}\left(\AA^{2}\right) * N_{A}\left(\mathrm{~mol}^{-1}\right) * 10^{-20}\left(\frac{\mathrm{m}^{2}}{\AA^{2}}\right)
$$

Where $\mathrm{N}_{\mathrm{A}}$ is Avogadro's constant, and $\sigma_{0}$ is the cross-sectional area of the probe gas molecule.

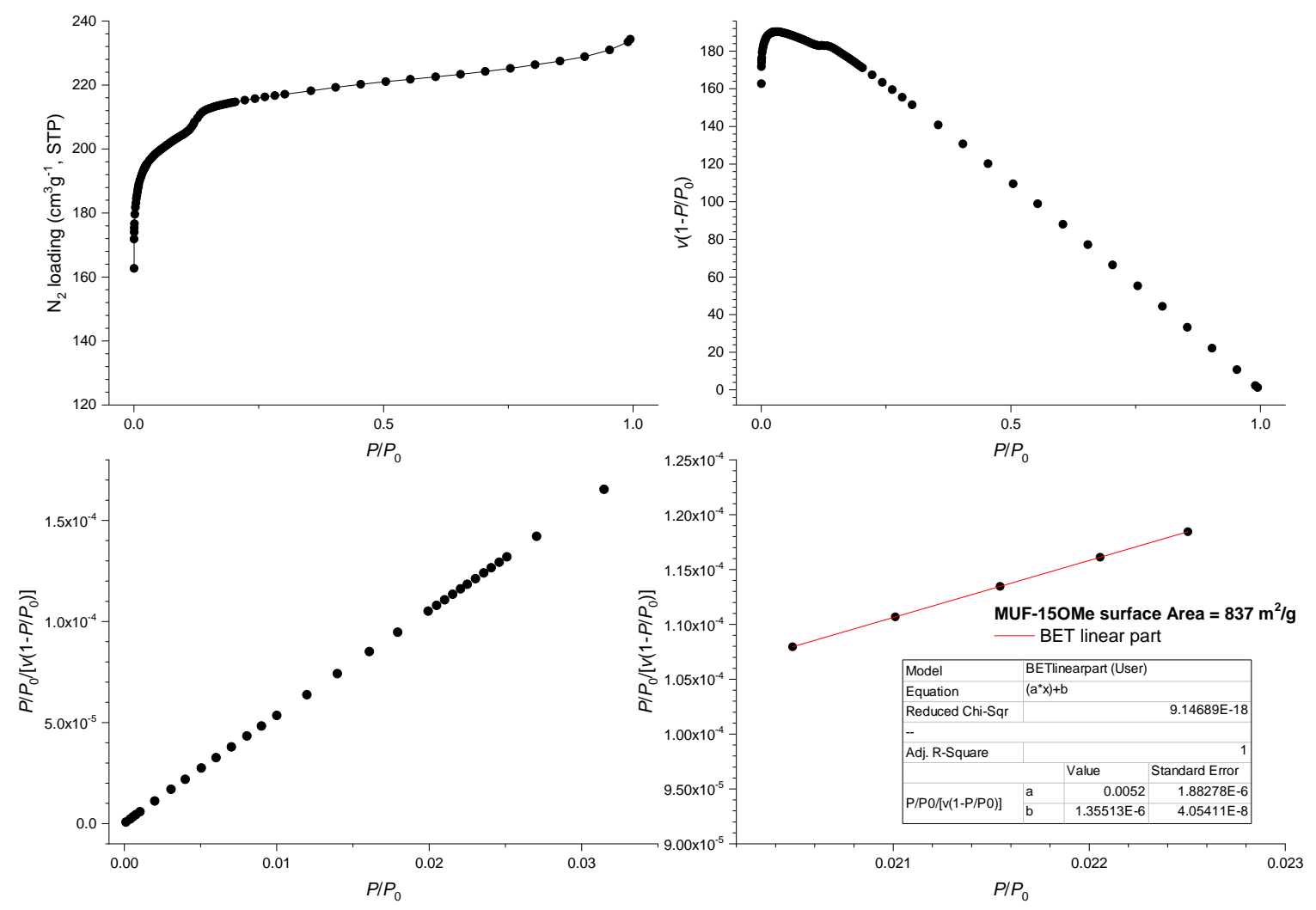

Figure S18. $\mathrm{N}_{2}$ adsorption isotherm at $77 \mathrm{~K}$ and BET surface area plots for MUF-15-OMe.

\section{Isosteric heats of adsorption ${ }^{8}$}

Isosteric heat of adsorption $\left(\mathrm{Q}_{\mathrm{st}}\right)$ values were calculated from isotherms measured at $273 \mathrm{~K}$ and $293 \mathrm{~K}$. These isotherms were first fit to a viral equation:

$$
\ln P=\ln N+\frac{1}{T} \sum_{i=0}^{m} a_{i} N^{i}+\sum_{i=0}^{n} b_{i} N^{i}
$$

Where $N$ is the amount of gas adsorbed at the pressure $P, a$ and $b$ are virial coefficients, $m$ and $n$ are the number of coefficients require to adequately describe the isotherm. To calculate $\mathrm{Q}_{\mathrm{st}}$, the fitting parameters from the above equation were used for the following equation:

$$
Q_{s t}=-R \sum_{i=0}^{m} a_{i} N^{i}
$$



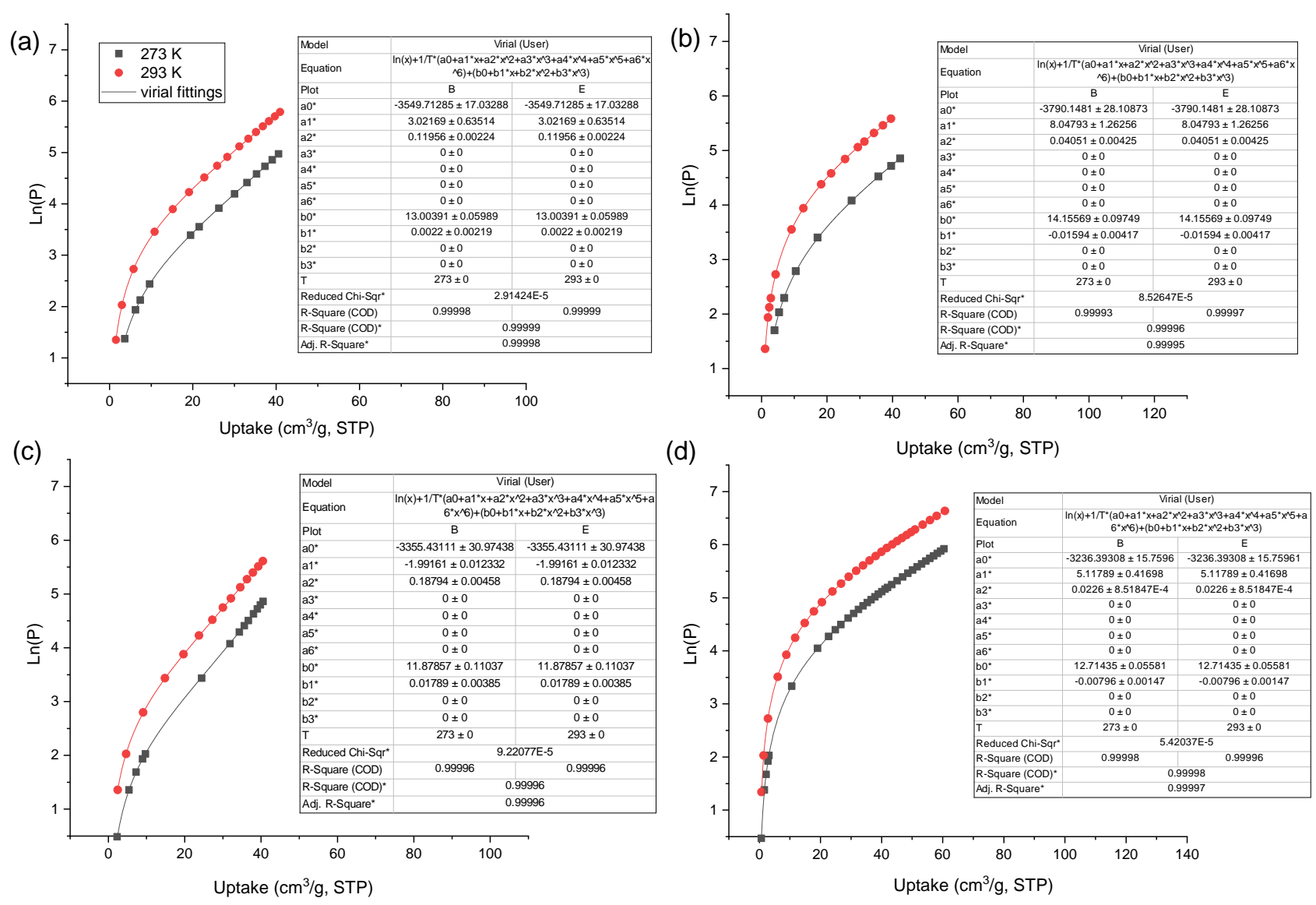

Figure S19. Virial equation fits for (a) $\mathrm{C}_{2} \mathrm{H}_{4}$, (b) $\mathrm{C}_{2} \mathrm{H}_{2}$, (c) $\mathrm{C}_{2} \mathrm{H}_{6}$ and (d) $\mathrm{CO}_{2}$ adsorption isotherms of MUF-15-OMe.

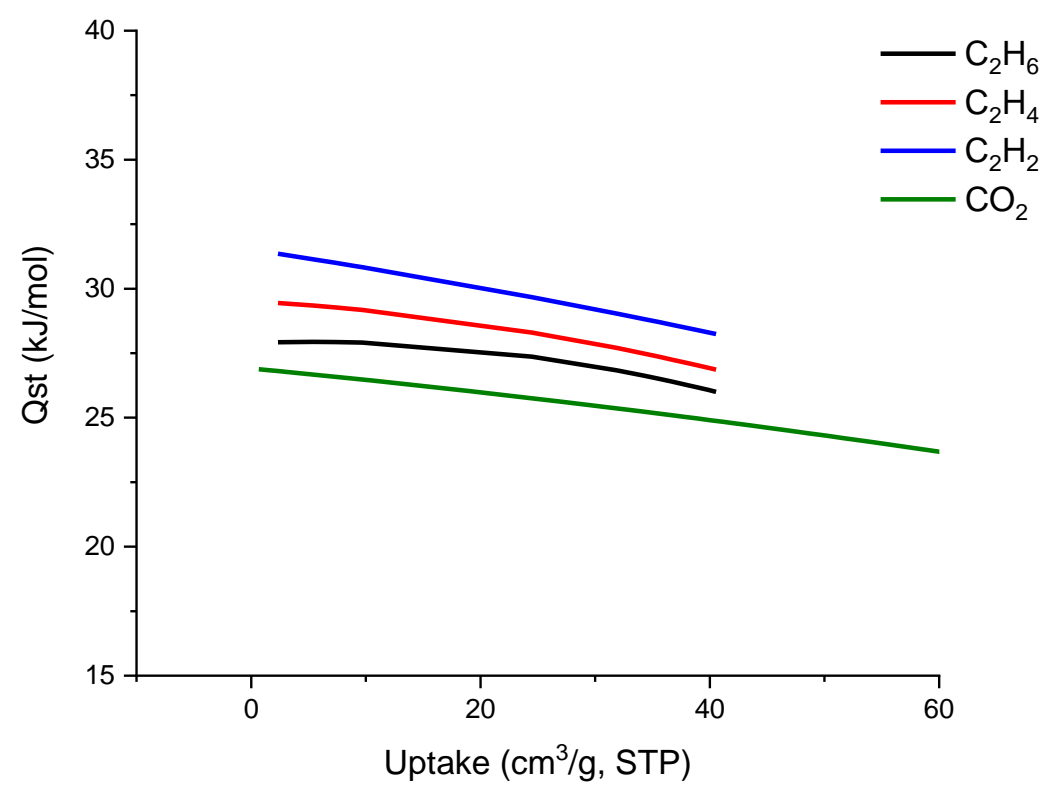

Figure S20. Isosteric heat of adsorption plots for the adsorption of various gases by MUF-15-OMe. 


\section{Breakthrough separation experiments and simulations}

A home-built breakthrough apparatus was used to measure the gas separation performance of the MOFs under dynamic conditions.

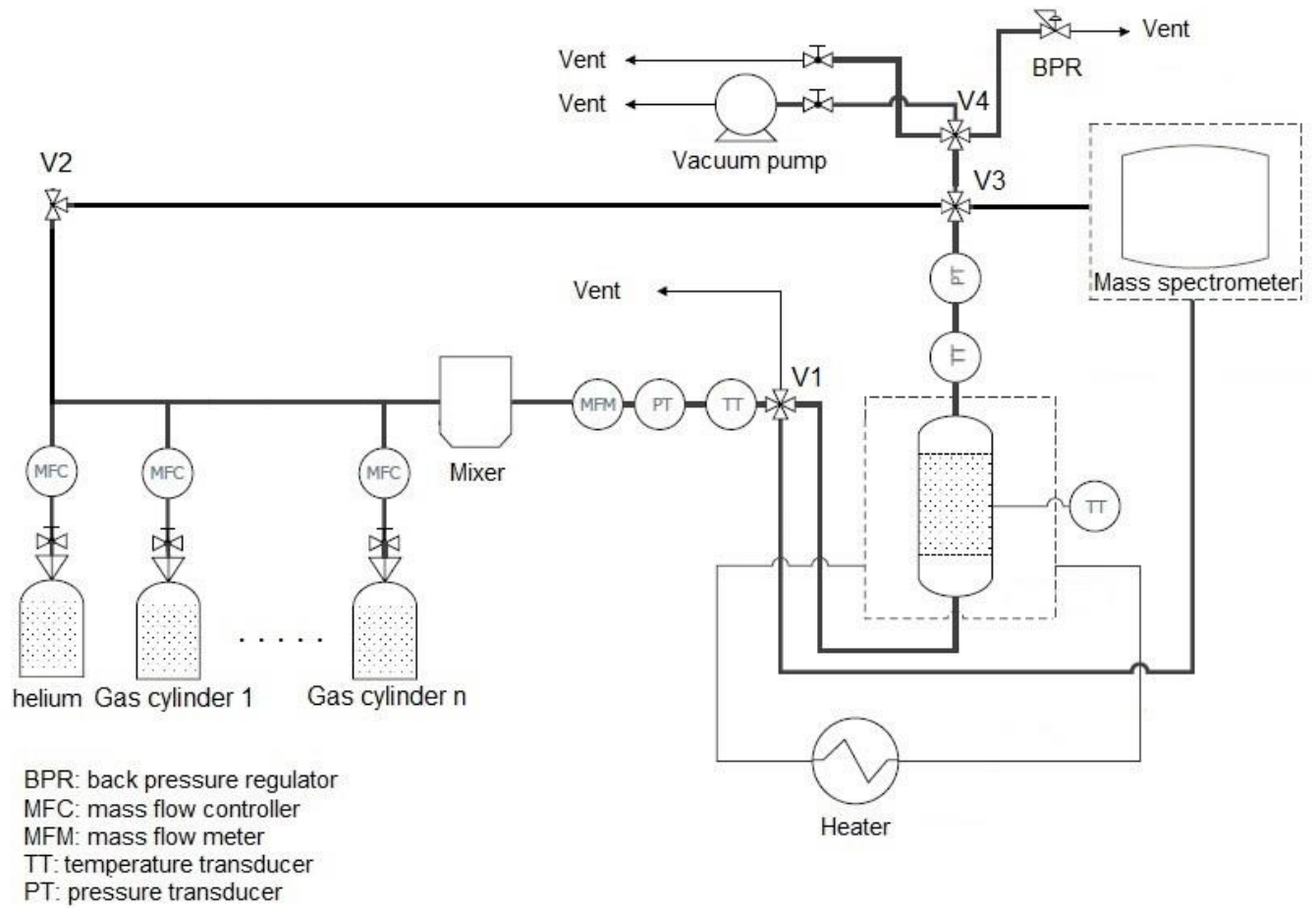

Figure S21. A schematic of the experimental column breakthrough setup.

\subsection{Single gas breakthrough experiments}

Activated MUF-15-OMe (0.85 g) was placed in an adsorption column $(6.4 \mathrm{~mm}$ in diameter $\times 11 \mathrm{~cm}$ in length) to form a fixed bed. The adsorbent was activated at $120{ }^{\circ} \mathrm{C}$ under high vacuum for 7 hours and then the column was left under vacuum for another 3 hours while being cooled to $20^{\circ} \mathrm{C}$. The column was then purged under a $20 \mathrm{mLN} / \mathrm{min}$ flow of He gas for $1 \mathrm{hr}$ at 1.1 bar prior to the breakthrough experiment. A gas mixture containing $\mathrm{CO}_{2} / \mathrm{He}$ was introduced to the column at 1.1 bar. The temperature of column was maintained at $273 \mathrm{~K}$ by placing it in a water/ice bath.

Feeds with different total flowrates but a constant flowrate of $\mathrm{CO}_{2}(3 \mathrm{~mL} / \mathrm{min})$ were introduced, as shown in Table S5. The operating pressure was controlled at 1.1 bar with a back-pressure regulator. The outlet composition was continuously monitored by a SRS UGA200 mass spectrometer.

Table S5. Feed composition for single gas breakthrough experiments.

\begin{tabular}{ccccc}
\hline $\begin{array}{c}\text { Inlet } \\
\text { mixture } \\
\left(\mathrm{CO}_{2} / \mathrm{He}\right)\end{array}$ & $\begin{array}{c}\mathrm{CO}_{2} \text { partial } \\
\text { pressure (torr) }\end{array}$ & $\begin{array}{c}\mathrm{CO}_{2} \text { flow rate } \\
\left(\mathrm{ml}_{N} / \mathrm{min}\right)\end{array}$ & $\begin{array}{c}\text { Helium flow rate } \\
\left(\mathrm{ml}_{\mathrm{N}} / \mathrm{min}\right)\end{array}$ & Total pressure (bar) \\
\hline $50 / 50$ & 412 & 3 & 3 & 1.1 \\
$60 / 40$ & 495 & 3 & 2 & 1.1 \\
$70 / 30$ & 577 & 3 & 1.28 & 1.1 \\
$95 / 5$ & 783 & 3 & 0.16 & 1.1 \\
\hline
\end{tabular}




\subsection{Mixed gas breakthrough experiments}

A similar procedure was used for the breakthrough measurements of $\mathrm{CO}_{2} / \mathrm{N}_{2}$ mixtures. The feed specifications are presented in Table S5.

Table S6. Feed composition for the $\mathrm{CO}_{2} / \mathrm{N}_{2}$ gas breakthrough experiments.

\begin{tabular}{ccccc}
\hline Inlet mixture & $\begin{array}{c}\mathrm{CO}_{2} \text { partial pressure } \\
\text { (torr) }\end{array}$ & $\begin{array}{c}\mathrm{CO}_{2} \text { flow rate } \\
\left(\mathrm{ml}_{N} / \mathrm{min}\right)\end{array}$ & $\mathrm{N}_{2}$ flow rate $\left(\mathrm{ml}_{\mathrm{N}} / \mathrm{min}\right)$ & Total pressure (bar) \\
\hline $60 / 40$ & 495 & 3 & 2 & 1.1 \\
$85 / 15$ & 701 & 3 & 0.52 & 1.1 \\
\hline
\end{tabular}

\subsection{Simulations of breakthrough curves}

Considering a fixed bed adsorption column of length L filled with MUF-15-OMe, following assumptions were made to develop a mathematical model ${ }^{9-11}$ that could be solved using proper numerical methods to calculate the concentration of gasses at different elapsed times along the bed.

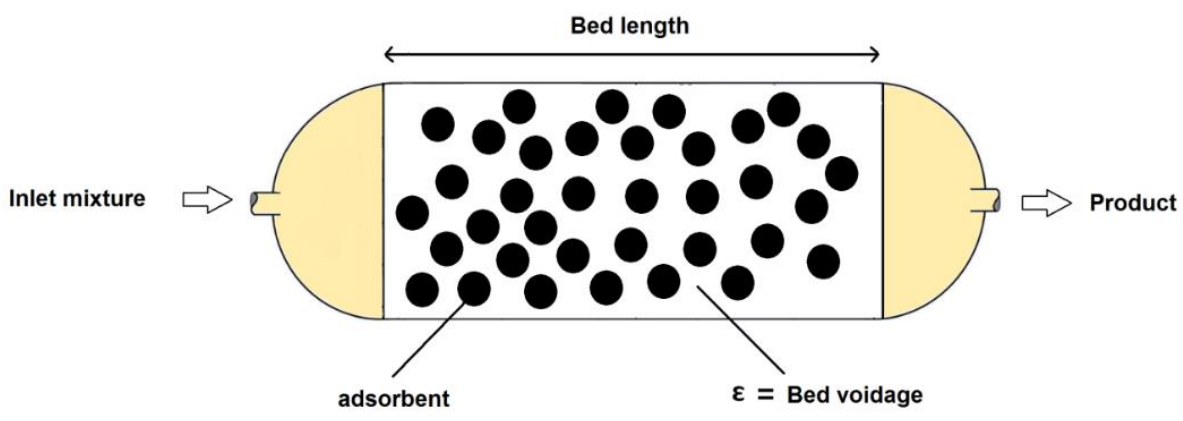

Figure S22. Schematic diagram of a fixed adsorption bed

The following assumptions were made:

- The dynamic behaviour of the fluid obeys an axial dispersion plug flow model in the bed.

- The gradient of the concentration along the radial and angular directions are neglected.

- The flow velocity is varied along the bed and it is calculated from the total mass balance equation.

- $\quad$ The gas property is described by the Peng-Robinson equation of state.

- Diffusion and adsorption into the particles is assumed as a lump kinetic transfer model.

- The mass transfer rate is represented by the linear driving force model.

- $\quad$ The pressure drop is considered along the bed using the Ergun equation.

- $\quad$ The adsorption columns operate under isothermal conditions.

- $\quad$ Mixed gas isotherms are calculated by Extended Dual-Site Langmuir Freundlich (DSLF) method. ${ }^{12}$

Based on the preceding assumptions, the component and overall mass balances in the bulk phase of the adsorption column are written as follow:

$$
\begin{aligned}
& \varepsilon \frac{\partial C_{i}}{\partial t}=-\frac{\partial\left(u C_{i}\right)}{\partial z}+\varepsilon D_{a x, i} \frac{\partial^{2} C_{i}}{\partial z^{2}}-(1-\varepsilon) \rho_{s} \frac{\partial q_{i}}{\partial t} \\
& \varepsilon \frac{\partial C}{\partial t}=-\frac{\partial(u C)}{\partial z}-(1-\varepsilon) \rho_{s} \sum_{1}^{n_{c}}\left(\frac{\partial q_{i}}{\partial t}\right)
\end{aligned}
$$


Where $\mathrm{C}_{\mathrm{i}}$ and $\mathrm{q}_{\mathrm{i}}$ are, respectively, concentration of components in the gas phase and in the adsorbed phase, $\mathrm{z}$ is the axial coordinate in the bed, $D_{\mathrm{ax}}$ is the effective axial dispersion coefficient, $u$ is the superficial gas velocity, $\rho_{\mathrm{s}}$ is the adsorbent density, $\mathrm{n}_{\mathrm{c}}$ is the number of the adsorbed components in the mixture and $\varepsilon$ is the bed voidage. The value of $\mathrm{D}_{\mathrm{ax}}$ was calculated through the following equation ${ }^{13}$ :

$\frac{\varepsilon D_{a x, i}}{D_{m, i}}=20+0.5 S c_{i} R e$

Where $R e$ is the Reynolds number and $\mathrm{Sc}$ is the Schmidt number and $\mathrm{D}_{\mathrm{m}, \mathrm{i}}$ is the molecular diffusivity of component $i$ in the mixture which was calculated by following equation:

$D_{m, i}=\frac{1-y_{i}}{\sum_{x=j}^{n} \frac{y_{i}}{D_{i, x}}}$

Where $\mathrm{y}_{\mathrm{i}}$ is the mole fraction of component $i$ and $\mathrm{D}_{\mathrm{i}, \mathrm{x}}$ is molecular diffusivity of component $i$ in component $\mathrm{x}$ which was calculated by Wile-Lee equation ${ }^{14}$. Referring to the assumptions, the solid linear driving force (LDF) model is used to describe the mass transfer rate of the gas and solid phase ${ }^{15}$ :

$\frac{\partial q_{i}}{\partial t}=k_{i}\left(q_{i}^{*}-q_{i}\right)$

Where $\mathrm{k}_{\mathrm{i}}$ is the overall mass transfer coefficient, and a lumped parameter considering three different mass transfer resistances associated with film, macropore and micropore zone. $\mathrm{q}_{\mathrm{i}}{ }^{*}$ is the equilibrium concentration of $i$ th component in the adsorbed phase and is related to the concentration in the gas phase through isotherms. The Extended Dual-Site Langmuir Freundlich method was used to predict the isotherm of gases in the mixture as below: ${ }^{12}$

$q_{i}^{*}=\frac{q_{1} b_{1} P^{1 / t_{1}}}{1+\sum_{j=1}^{n} b_{1} P^{1 / t_{1}}}+\frac{q_{2} b_{2} P^{1 / t_{2}}}{1+\sum_{j=1}^{n} b_{2} P^{1 / t_{2}}}$

To calculate mixed gas isotherms, the single-component adsorption isotherms of $\mathrm{CO}_{2}$ and $\mathrm{N}_{2}$ were first fit to either single-site Langmuir (for $\mathrm{CO}_{2}$ before cut-off) and dual site Freundlich Langmuir model (for $\mathrm{N}_{2}$ and $\mathrm{CO}_{2}$ full isotherm) as below to calculate fitting parameters:

$q=\frac{q_{1} b_{1} P}{1+b_{1} P}$

$q=\frac{q_{1} b_{1} P^{1 / t_{1}}}{1+b_{1} P^{1 / t_{1}}}+\frac{q_{2} b_{2} P^{1 / t_{2}}}{1+b_{2} P^{1 / t_{2}}}$

Where $\mathrm{q}$ is the uptake of a gas; $\mathrm{P}$ is the equilibrium pressure and $\mathrm{q}_{1}, \mathrm{~b}_{1}, \mathrm{q}_{2}, \mathrm{~b}_{2}, \mathrm{t}_{1}$ and $\mathrm{t}_{2}$ are constants. The fitting parameters are shown in the following figures. 


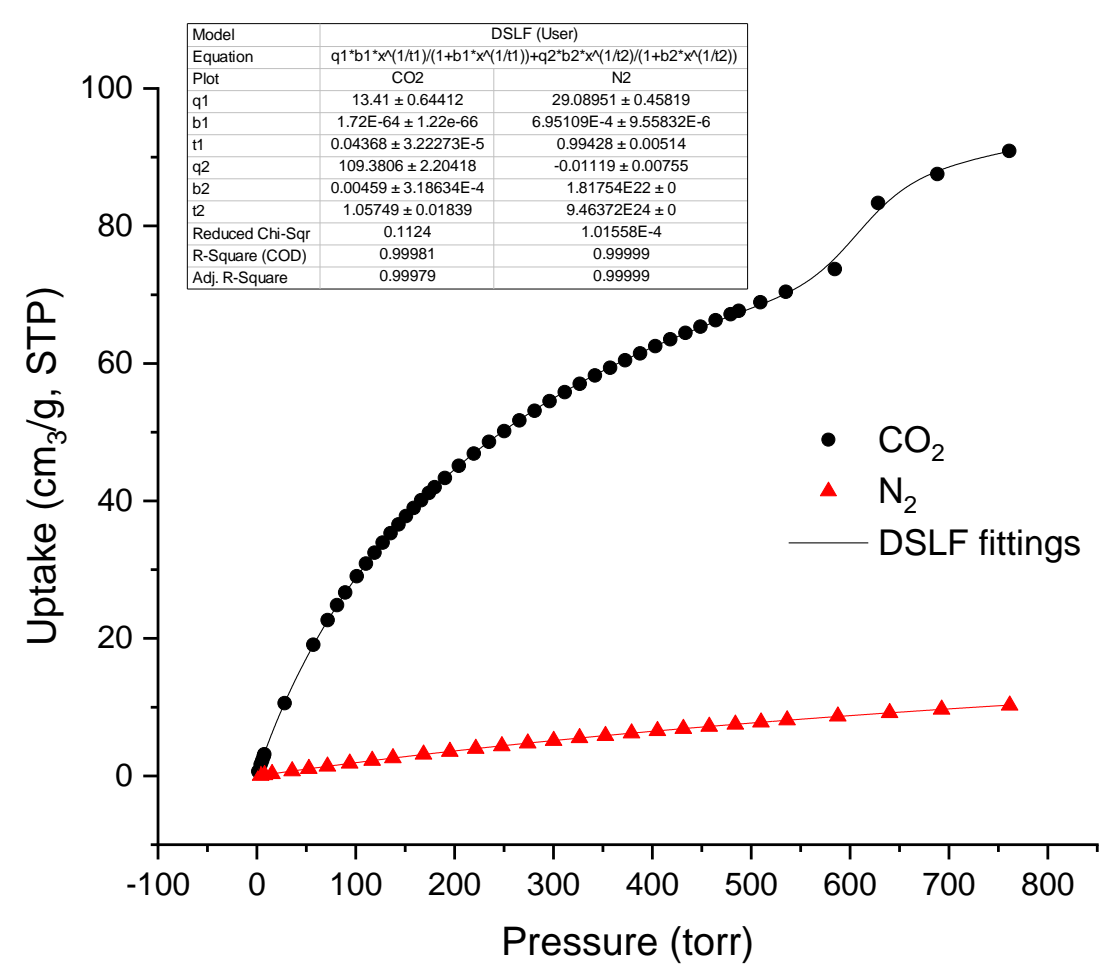

Figure S23. Dual-site Langmuir Freundlich fits of the MUF-15-OMe isotherms at 273 K.

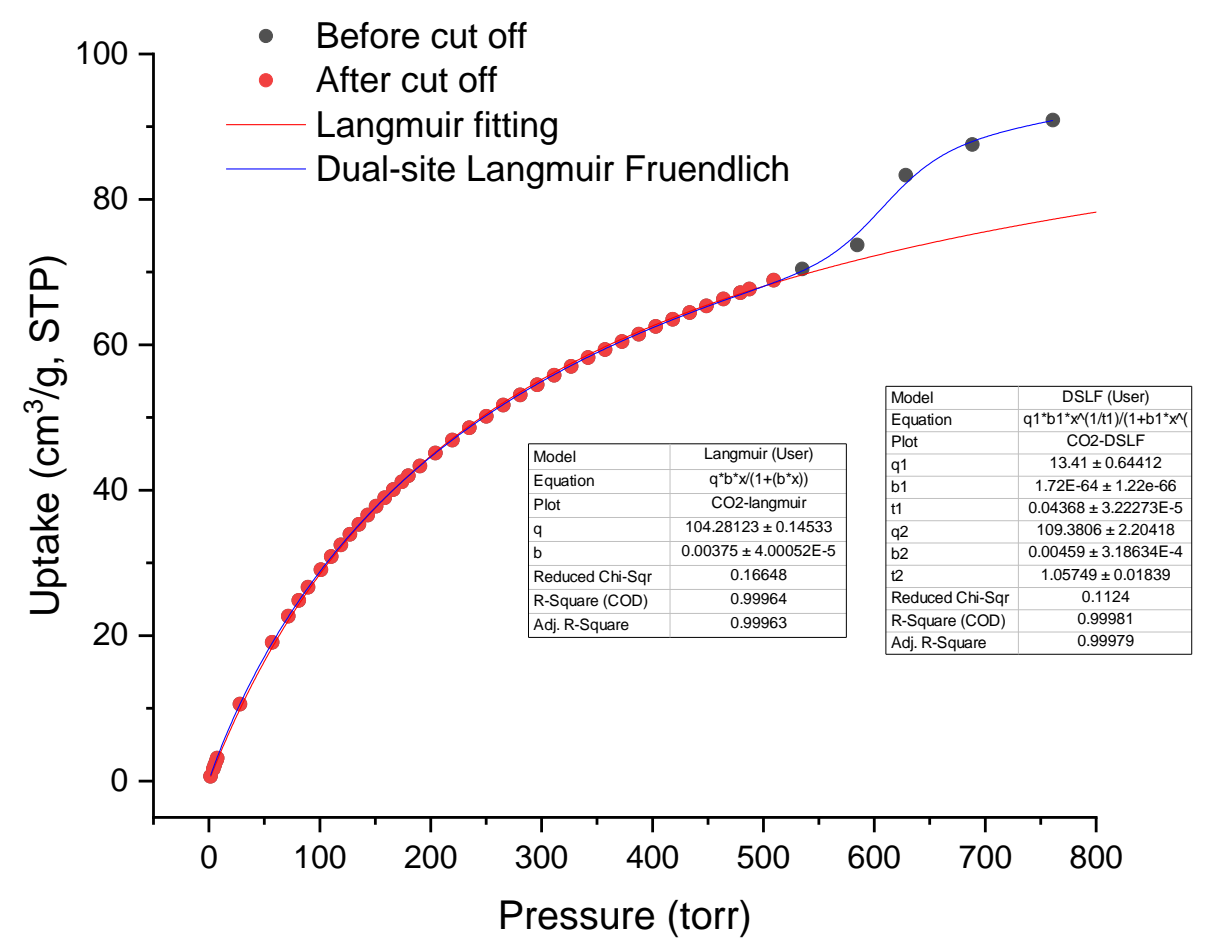

Figure S24. Parameters for the $\mathrm{CO}_{2}$ adsorption isotherm of MUF-15-OMe at $273 \mathrm{~K}$ using two different fitting methods. A Langmuir model was used for the points below 510 Torr and a DSLF model was used for the full isotherm. 
The pressure drop is defined by Ergun's equation as ${ }^{16}$ :

$\frac{\partial P}{\partial z}=-\left(\frac{37.5(1-\varepsilon)^{2} \mu u}{\left(r_{p} \varphi\right)^{2} \varepsilon^{3}}+0.875 \rho \frac{(1-\varepsilon) u^{2}}{r_{p} \varphi \varepsilon^{3}}\right)$

Where $P$ is the local pressure at the $z$ axial coordinate, $\mu$ is the gas viscosity, $\varphi$ is the shape factor and $\rho$ is the gas density. Identical conditions to the experimental breakthrough measurement, including operating pressure, feed flowrate, temperature, bed size and amount of MOF, were used as input for simulations. All the parameters used for the simulations are tabulated in Table S6.

Tuning of mass transfer coefficients: As the overall mass transfer coefficient $\left(\mathrm{k}_{\mathrm{i}}\right)$ is in proportion to the steepness of breakthrough curves, the accurate value of it was obtained empirically by tuning its value until the steepness of the predicted and experimental breakthrough curves were the same. This mass transfer coefficient tuned in this way was later used to predict breakthrough curves for other feed mixtures and operating pressures. In this study, mass transfer coefficients of $0.0085 \mathrm{~s}^{-1}$ and $0.0133 \mathrm{~s}^{-1}$ were found to be the optimum values, leading to a satisfactory match between predicted and experimental breakthrough curves before and after flexing for all mixture compositions.

Table S7. Adsorption column parameters and feed characterizations used for the simulations for MUF-15-OMe.

\section{Adsorption bed}

Length: $110 \mathrm{~mm}$

Diameter: $6.4 \mathrm{~mm}$

Amount of adsorbent in the bed: $0.85 \mathrm{~g}$

Bed voidage: 0.5

Adsorbent average radius: $0.05 \mathrm{~mm}$

$\mathrm{k}_{\mathrm{CO} 2}$ : $0.0085 \mathrm{~s}^{-1}$ before flexing and $0.0133 \mathrm{~s}^{-1}$

after flexing

$\mathrm{k}_{\mathrm{N} 2}: 0.02 \mathrm{~s}^{-1}$

\section{Isotherm data}

Figures above

\section{Feed}

Table S5 and S6

Numerical solutions of the nonlinear parabolic PDEs derived from mass and momentum balance were conducted by an implicit method of lines using finite difference method for the spatial derivatives. Firstly, the second and first space derivatives were discreted by central and upwind- differential scheme (backward), respectively. In this way, the sets of partial equations were transformed to the sets of ODEs with respect to the time derivative terms. The length of the bed was divided into 50 increments and the set of equations were solved by the Implicit Euler method with a time step of one second. ${ }^{17}$ 

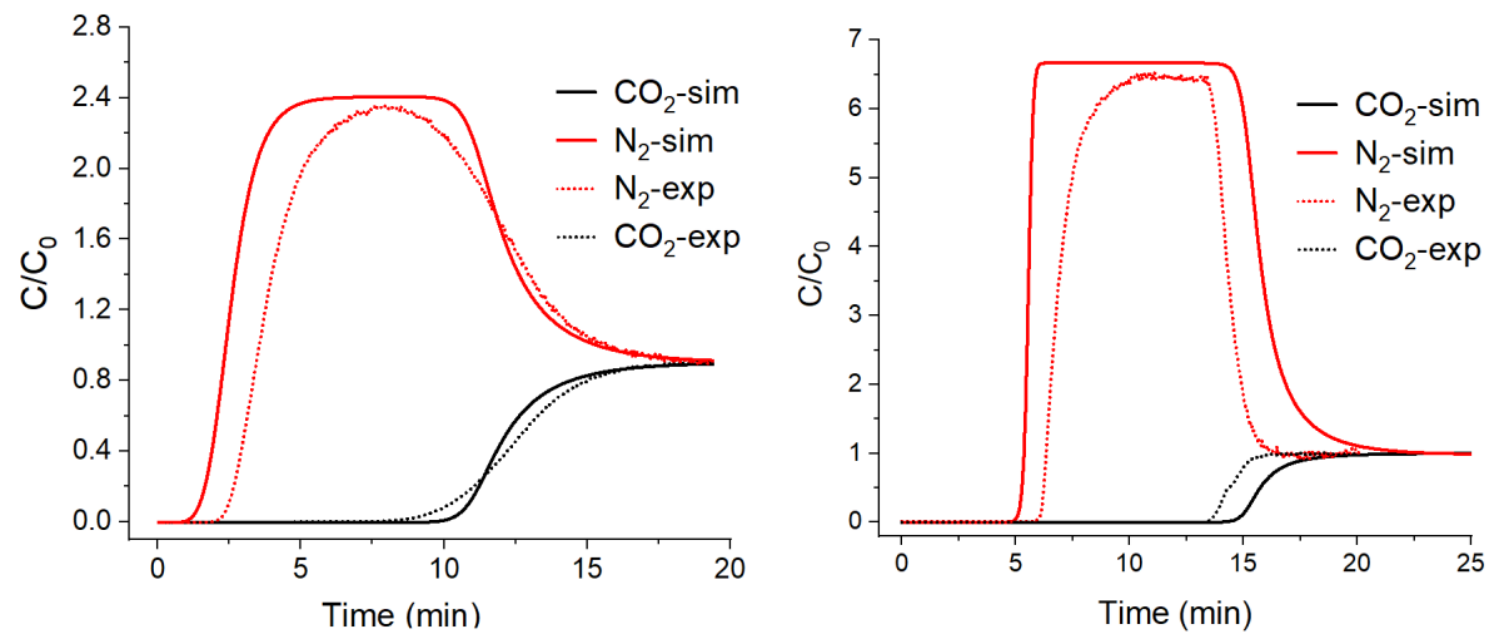

Figure S25. Experimental and predicted breakthrough curves for a mixture of (left) $60 / 40 \mathrm{CO}_{2} / \mathrm{N}_{2}\left(\mathrm{CO}_{2}\right.$ partial pressure of 495 torr) and (right) $85 / 15 \mathrm{CO}_{2} / \mathrm{N}_{2}\left(\mathrm{CO}_{2}\right.$ partial pressure of 701 torr) in column packed with MUF-15-OMe at $273 \mathrm{~K}$ and 1.1 bar.

\section{9. ${ }^{1} \mathrm{H}$ NMR spectroscopy}

A Bruker Avance $500 \mathrm{MHz}$ NMR was used to collect the ${ }^{1} \mathrm{H}$ NMR spectroscopic data. A stock solution of $9.5 \mathrm{~mL} \mathrm{D}_{2} \mathrm{O}$ and $0.5 \mathrm{~mL} \mathrm{NaOD}$ was prepared. A small number of crystals (approximately $5-15 \mathrm{mg}$ ) were vacuum dried for 20 minutes then heated in a dry bath to approximately $105^{\circ} \mathrm{C}$ for 1 hour. The crystals were then digested in $750 \mu \mathrm{L}$ of the $\mathrm{D}_{2} \mathrm{O} / \mathrm{NaOD}$ solution. A brown precipitate formed which was left to settle before the liquid was transferred into an NMR tube and the spectrum was acquired. The peak at $\delta 3.18$ ppm belongs to $\mathrm{MeOH}$.

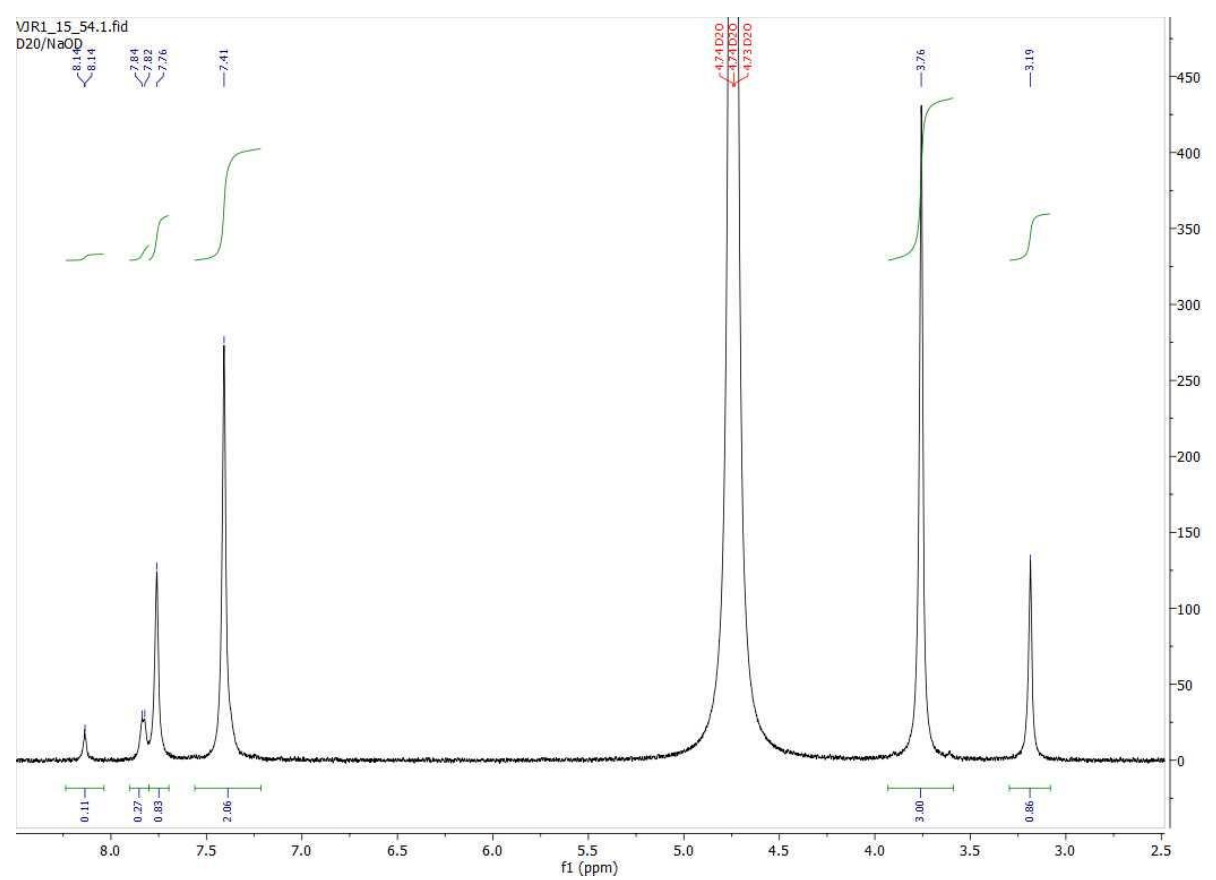

Figure S26. ${ }^{1} \mathrm{H}$ NMR spectrum of $\left[\mathrm{Co}_{6}\left(\mu_{3}-\mathrm{OH}\right)_{2}(\mathrm{ipa})_{0.59}(\mathrm{ipa}-\mathrm{OMe})_{4.42}\left(\mathrm{H}_{2} \mathrm{O}\right)_{4}\right]$ digested in $\mathrm{D}_{2} \mathrm{O} / \mathrm{NaOD}$. 


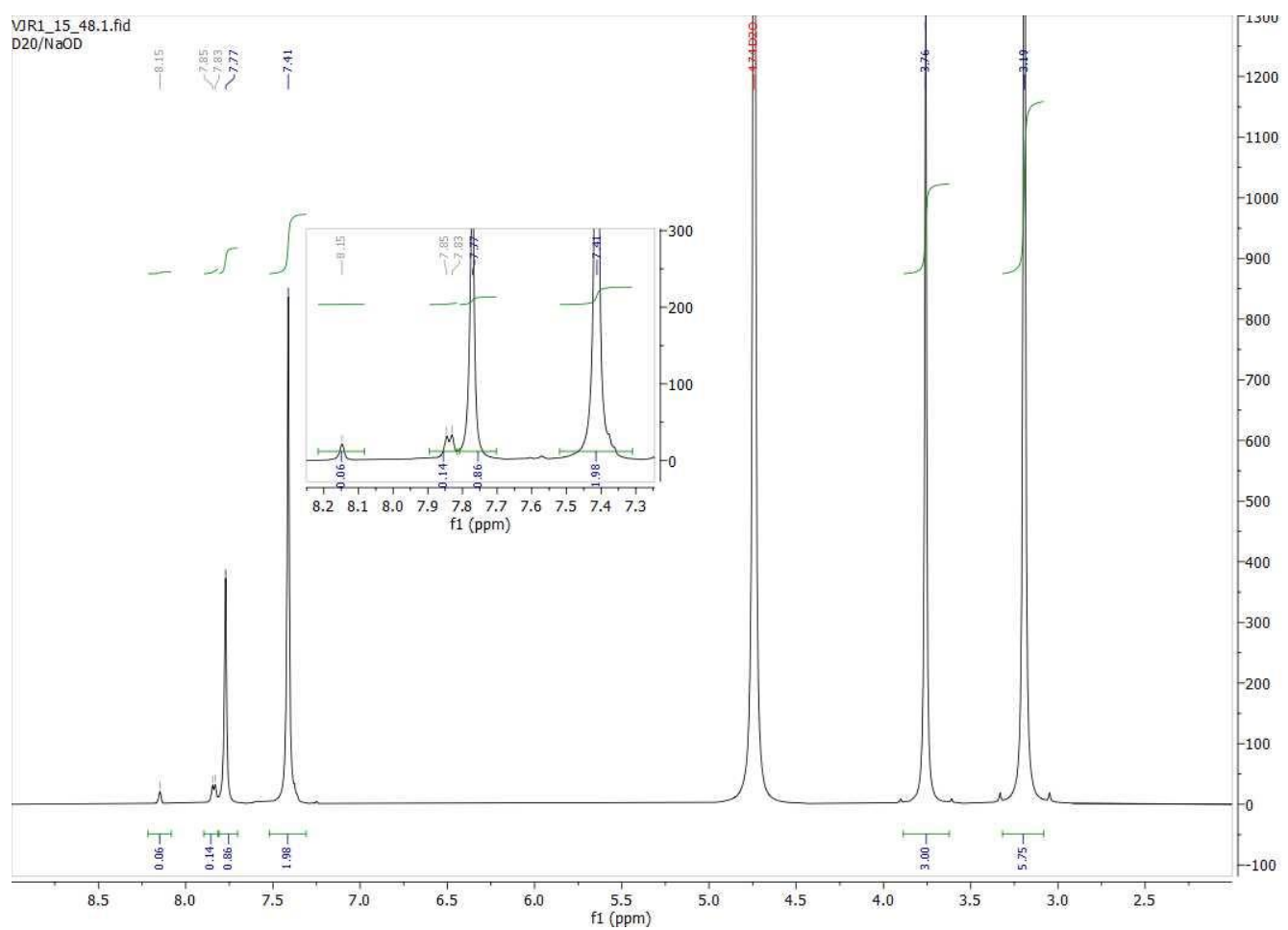

Figure S27. ${ }^{1} \mathrm{H}$ NMR spectrum of $\left[\mathrm{Co}_{6}\left(\mu_{3}-\mathrm{OH}\right)_{2}(\mathrm{ipa})_{0.33}(\mathrm{ipa}-\mathrm{OMe})_{4.68}\left(\mathrm{H}_{2} \mathrm{O}\right)_{4}\right]$ digested in $\mathrm{D}_{2} \mathrm{O} / \mathrm{NaOD}$.

\section{Computational methods}

The structures were investigated at the Density Functional Theory (DFT) level with CRYSTAL17 code. ${ }^{18}$ All-electron Gaussian basis sets of double- $\zeta$ valence with polarization were used for all the atoms. These basis sets can be found on the online CRYSTAL basis sets library (https://www.crystal.unito.it/basis-sets.php). Exchange and correlation potential was treated at the hybrid level of approximation with the PBESOL0 functional. ${ }^{19}$ Considering the large size of the system, a unique $k$-point for the sampling of the Brillouin zone was enough to converge the properties of interest.

Convergence criteria for the geometry optimization were kept at their default values: a maximum of 0.00045 a.u. on atomic displacements during one optimization step and 0.0018 a.u. on forces. Once the structures were converged, we used the Zeo++ software package ${ }^{1}$ to calculate the accessible volume and surface area based on geometric considerations. Representative input files for the calculations are available online at https://github.com/fxcoudert/citable-data

Calculations were performed on the parent MUF-15 compound in the Pnna space group. The space group symmetry was maintained throughout the calculations. 


\section{1. $\mathrm{H}_{2} / \mathrm{D}_{2}$ separations ${ }^{20,21}$}

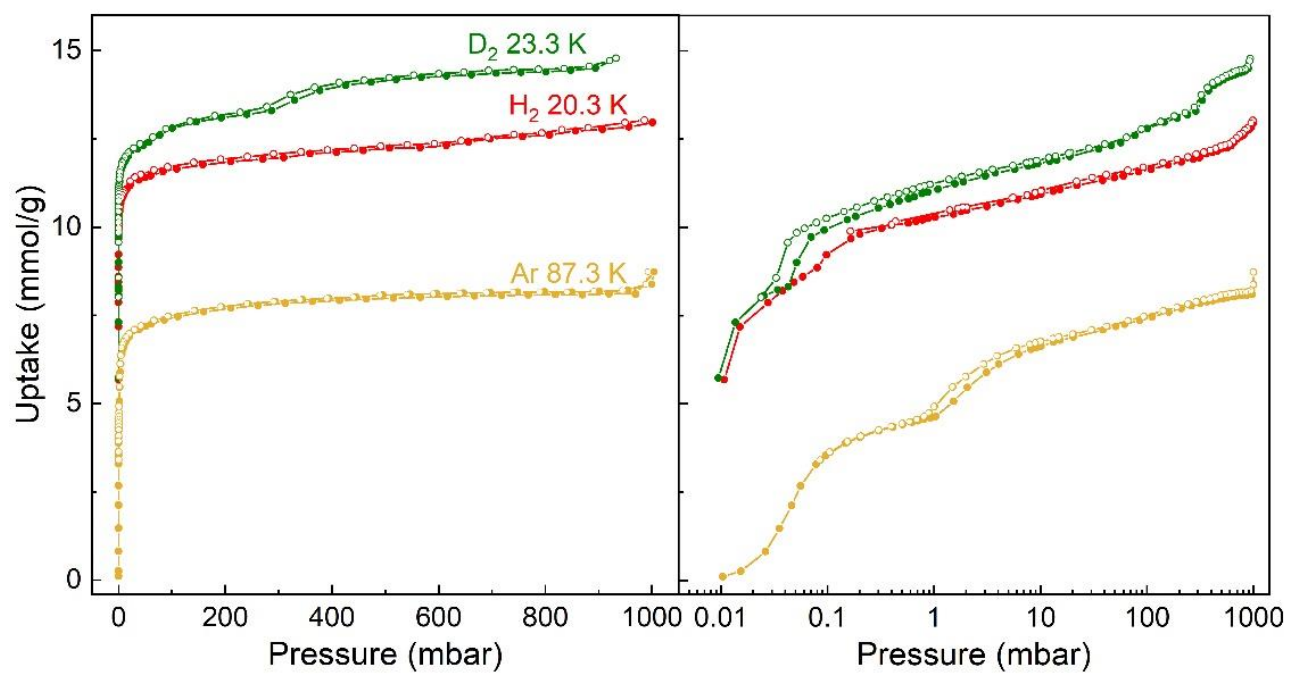

Figure S28. MUF-15-OMe isotherms for $\mathrm{H}_{2}$ at $20.3 \mathrm{~K}, \mathrm{D}_{2}$ at $23.3 \mathrm{~K}$ and $\mathrm{Ar}$ at $87.3 \mathrm{~K}$ in a linear (left) and semi-logarithmic representation (right). Ad- and desorption points are distinguished by filled and empty symbols. Isotherms were collected on a iQ2 Autosorb apparatus with a minimal equilibrium time of 20 minutes.

Low-temperature thermal desorption spectroscopy: Calibration was carried out according to ref ${ }^{20}$. 

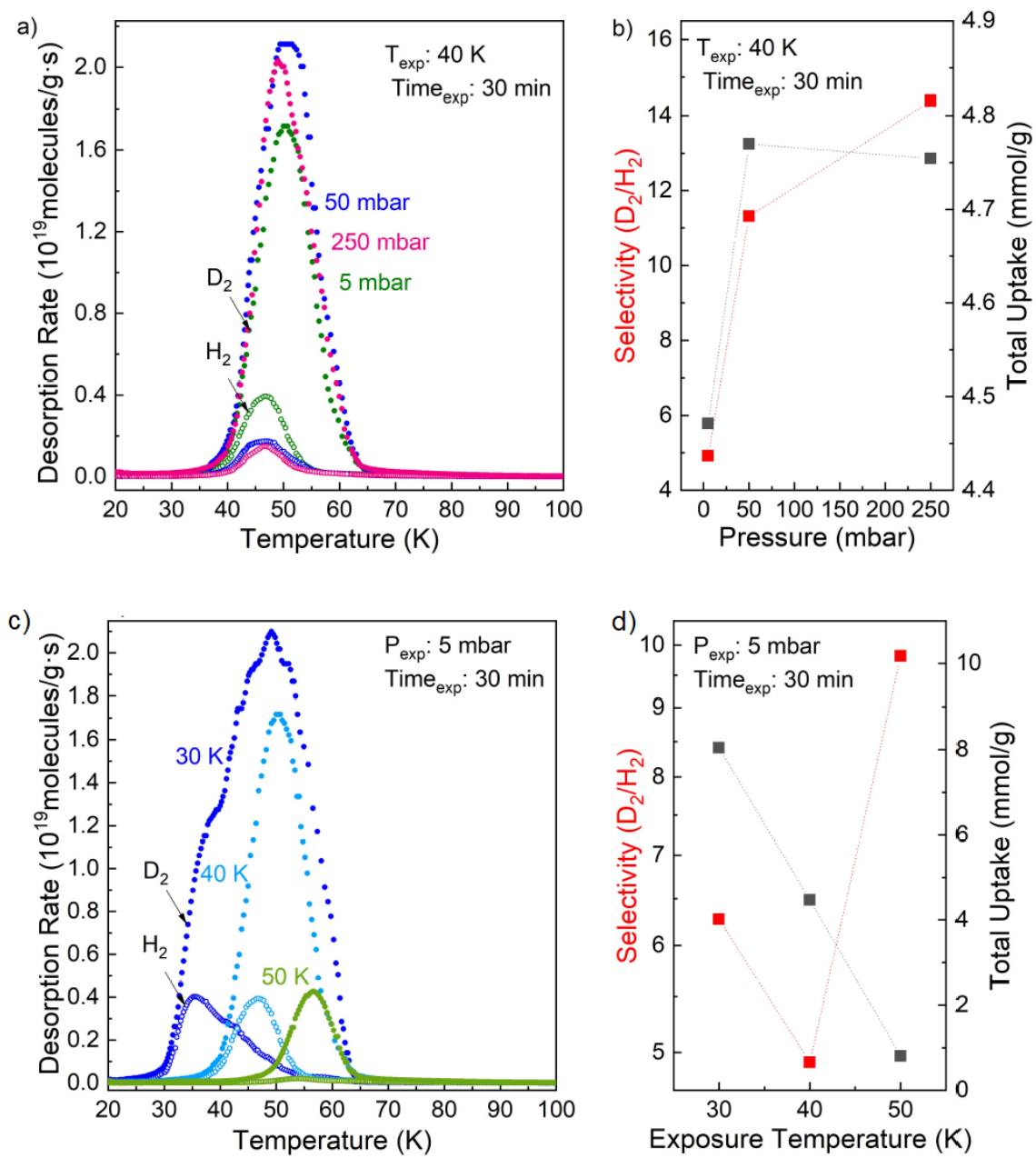

Figure S29. Desorption of MUF-15-OMe for 5, 50 and 250 mbar exposure pressures: a) TDS desorption rate at $40 \mathrm{~K}$ exposure temperature and $30 \mathrm{~min}$ exposure time; b) selectivity and total uptake as a function of exposure pressure. Desorption of MUF-15-OMe for 30, 40 and $50 \mathrm{~K}$ exposure temperature: c) TDS desorption rate at 5 bar exposure pressure and 30 min exposure time; d) selectivity and total uptake as a function of exposure temperature. 


\section{References}

1. Willems, T. F.; Rycroft, C. H.; Kazi, M.; Meza, J. C.; Haranczyk, M., Algorithms and tools for highthroughput geometry-based analysis of crystalline porous materials. Microporous Mesoporous Mater. 2012, 149 (1), 134-141.

2. Dubbeldam, D.; Calero, S.; Ellis, D. E.; Snurr, R. Q., RASPA: molecular simulation software for adsorption and diffusion in flexible nanoporous materials. Mol. Simul. 2016, 42 (2), 81-101.

3. Li, J.-R.; Kuppler, R. J.; Zhou, H.-C., Selective gas adsorption and separation in metal-organic frameworks. Chem. Soc. Rev. 2009, 38 (5), 1477-1504.

4. Eguchi, R.; Uchida, S.; Mizuno, N., Inverse and High $\mathrm{CO}_{2} / \mathrm{C}_{2} \mathrm{H}_{2}$ Sorption Selectivity in Flexible OrganicInorganic lonic Crystals. Angew. Chem., Int. Ed. 2012, 51 (7), 1635-1639.

5. Reid, C. R.; Thomas, K. M., Adsorption Kinetics and Size Exclusion Properties of Probe Molecules for the Selective Porosity in a Carbon Molecular Sieve Used for Air Separation. J. Phys. Chem. B 2001, 105 (43), 10619-10629.

6. Li, L.; Lin, R.-B.; Wang, X.; Zhou, W.; Jia, L.; Li, J.; Chen, B., Kinetic separation of propylene over propane in a microporous metal-organic framework. Chem. Eng. J. 2018, 354, 977-982.

7. Walton, K. S.; Snurr, R. Q., Applicability of the BET Method for Determining Surface Areas of Microporous Metal-Organic Frameworks. J. Am. Chem. Soc. 2007, 129, 8552-8558.

8. Dincă, M.; Dailly, A.; Liu, Y.; Brown, C. M.; Neumann, D. A.; Long, J. R., Hydrogen Storage in a Microporous Metal-Organic Framework with Exposed Mn2+ Coordination Sites. J. Am. Chem. Soc. 2006, 128 (51), 16876-16883.

9. Qazvini, O. T.; Fatemi, S., Modeling and simulation pressure-temperature swing adsorption process to remove mercaptan from humid natural gas; a commercial case study. Sep. Purif. Technol. 2015, 139, 88103.

10. Mehdipour, M.; Fatemi, S., Modeling of a PSA-TSA Process for Separation of CH4from C2Products of OCM Reaction. Sep. Sci. Technol. 2012, 47 (8), 1199-1212.

11. Chahbani, M. H.; Tondeur, D., Mass transfer kinetics in pressure swing adsorption. Sep. Purif. Technol. 2000, 20 (2), 185-196.

12. Do, D. D., Adsorption analysis: equilibria and kinetics. Imperial college press London: 1998; Vol. 2.

13. Bird, R. B., Transport phenomena. Applied Mechanics Reviews 2002, 55 (1), R1-R4.

14. Perry, R.; Green, D.; Maloney, J., Chemical engineers handbook. 8th edition ed.; The McGraw Hill Companies, Inc: 2008.

15. Farooq, S.; Ruthven, D. M., A comparison of linear driving force and pore diffusion models for a pressure swing adsorption bulk separation process. Chem. Eng. Sci. 1990, 45 (1), 107-115.

16. Yang, R. T., Gas separation by adsorption processes. Butterworth-Heinemann: 2013.

17. Kiusalaas, J., Numerical methods in engineering with Python 3. Cambridge university press: 2013.

18. Dovesi, R.; Erba, A.; Orlando, R.; Zicovich - Wilson, C. M.; Civalleri, B.; Maschio, L.; Rérat, M.; Casassa, S.; Baima, J.; Salustro, S., Quantum - mechanical condensed matter simulations with CRYSTAL. Wiley Interdisciplinary Reviews: Computational Molecular Science 2018, 8 (4), e1360.

19. Perdew, J. P.; Ruzsinszky, A.; Csonka, G. I.; Vydrov, O. A.; Scuseria, G. E.; Constantin, L. A.; Zhou, X.; Burke, K., Restoring the Density-Gradient Expansion for Exchange in Solids and Surfaces. Phys. Rev. Lett. 2008, 100 (13), 136406.

20. Von Zeppelin, F.; Haluška, M.; Hirscher, M., Thermal desorption spectroscopy as a quantitative tool to determine the hydrogen content in solids. Thermochim. Acta 2003, 404 (1-2), 251-258.

21. Panella, B.; Hirscher, M.; Ludescher, B., Low-temperature thermal-desorption mass spectroscopy applied to investigate the hydrogen adsorption on porous materials. Microporous Mesoporous Mater. 2007, 103 (1), 230-234. 